\title{
LOS VALORES ASPECTUALES EN EL ESPAÑOL MODERNO DE AMÉRICA EN LAS OBRAS DEL ESCRITOR COLOMBIANO GABRIEL GARCÍA MÁRQUEZ ${ }^{1}$
}

\section{Introducción}

El objetivo principal de este trabajo es dilucidar el papel de algunas formas verbales de español usadas para indicar los valores aspectuales en textos españoles contemporáneos. El estudio se limita a aquellas formas verbales que son portadoras primordiales de valores temporo-aspectuales en español. El análisis de estas formas verbales siempre se hace dentro de un amplio ambiente textual ya que se considera primordial el entorno dentro del cual actúan las formas verbales en concordancia con otros elementos lingüísticos. Se define el texto como un entorno natural compuesto de muchos factores de los que las formas verbales solamente son una piedra del mosaico textual.

El corpus seleccionado para este estudio es la obra narrativa de Gabriel García Márquez, y más concretamente cuatro novelas y un relato de este autor: La Hojarasca, Cien años de soledad, Crónica de una muerte anunciada, Relato de un náufrago, El amor en los tiempos del cólera. El motivo de esta selección del corpus reside, por una parte, en la prolijidad de la obra del autor colombiano que ofrece un corpus suficientemente amplio para el estudio de valores aspectuales $y$, por otra parte, en el hecho de que todas las obras narrativas del nobel colombiano han sido traducidas al esloveno, lo que presenta un apoyo importante - por el hecho de poder comparar los dos idiomas- en el estudio de este fenómeno lingüístico. Un factor decisivo para la selección del corpus es también el concepto del espacio y del tiempo de García Márquez ya que las formas verbales que indican las relaciones temporo-aspectuales podrían reflejar de alguna manera su concepto del tiempo. En el análisis de las formas verbales se consideró también el tipo del texto (crónica, novela, relato), las orientaciones narrativas (ordo naturalis, flashback, flashforward), la inclusión de otros discursos en el texto (discurso directo, discurso indirecto, discurso indirecto libre), el punto de mira del narrador (narrador omnisciente, narrador testigo, narrador protagonista), la puesta de relieve de las acciones (primer plano - segundo plano).

\section{Definición del concepto de valores aspectuales}

El problema del aspecto verbal es un tema polémico abordado desde los más distintos puntos de vista. Macaulay compara el estudio del aspecto a una selva salvaje, oscura y tupida

1 Este artículo es la presentación de la tesis doctoral de la autora dirigida por el dr. Mitja Skubic de la Universidad de Ljubljana y defendida en dicha universidad el 17 de marzo de 1998. La publicación del artículo fue posible gracias al apoyo del Instituto Científico de la Facultad de Filosofia y Letras de la Universidad de Ljubljana bajo los auspicios del cual se llevó a cabo la investigación sobre el aspecto verbal. 
llena de obstáculos, escollos y laberintos que atraparon a la mayoría de los que se aventuraron en ese territorio muy explorado pero con mapas mal trazados. ${ }^{2}$

La complejidad de la problemática del aspecto ha llevado a una confusión terminológica y conceptual. Generalmente se considera el aspecto como la manera de ver la organización interna de una acción ${ }^{3}$, es decir, la manera de percibir el tiempo interno de una acción. El aspecto parece ser una categoría universal que se manifiesta de distintas maneras en diferentes lenguas. Justamente este hecho ha llevado a generalizar el concepto de aspecto, típico de las lenguas eslavas, a otras lenguas, es decir, definir el aspecto como la manera de ver una acción en cuanto terminada (aspecto perfectivo) o no terminada (aspecto imperfectivo) y considerarlo como morfológico o gramatical distinto del aspecto semántico o léxico denominado Aktionsart. ${ }^{4}$ En torno al contenido del concepto de Aktionsart existe también una confusión, ya que se interpreta generalmente de dos maneras. Por una parte, se entiende con este término el significado inherente del verbo $y$, por otra parte, se define el concepto como una categoría morfológico-léxica en la que los matices de significado se dan mediante prefijos, sufijos, infijos y combinaciones verbales. En el primer caso con el Aktionsart se explica la diferencia de los verbos permanentes y desinentes, conceptos que introdujo Andrés Bello, es decir, la diferencia existente entre los verbos que expresan acciones télicas (acciones con límite) y los que expresan acciones atélicas (acciones sin límite) y que más tarde denominó Gili Gaya verbos imperfectivos y verbos perfectivos. La segunda acepción del término se refiere a las diferencias de significado dadas por distintos elementos morfológicos (besar-besuquear, abrir-reabrir, leer-releer, durar-perdurar) y morfo-sintácticos (perifrasis verbales).

La tradicional diferencia entre aspecto y Aktionsart fue aceptada y mantenida por la mayoría de los lingüistas hasta nuestros días. Pero la falta de una división clara de estos conceptos llevó a algunos estudiosos de la lengua como Lyons (1977), Coseriu (1980), Comrie (1976) a rechazar esta distinción y considerar el aspecto como un todo y no separar lo morfológico (gramatical) de lo semántico-léxico, y a otros, como Carlota Smith (1991), a enlazar los dos conceptos (el aspecto verbal en el sentido estrecho - imperfectivo/perfectivoy los tipos de acción) en la teoría de los dos componentes.

Debido a la ya mencionada amplitud y complejidad del concepto, el aspecto en este estudio se considera en su sentido amplio. Para definirlo se usan los términos de valores aspectuales o aspectualidad que cubren los siguientes conceptos ${ }^{5}$ :

2 Binnick, 1991, p. 135.

3 En este estudio, si no se indica de otra manera, acción significa acción propiamente dicha, proceso y estado.

4 En español prevalece la denominación modo de acción. Existen además otros términos: cualidad de la acción, tipo de acción, etc.

5 La definición general del concepto de aspectualidad se desprende de las definiciones de aspecto de los autores Miklic (1980, 1981, 1983), Comrie (1976), Coseriu (1980) y otros. 
a) las características del desarrollo de la acción verbal en el tiempo (acciones momentáneas, reiterativas, habituales, resultativas, etc.), lo que frecuentemente se denomina Aktionsart;

b) el tipo de la acción (estado, no estado, acciones télicas y atélicas);

c) las partes de la acción (incoativa, intermedia - durativa, terminativa), lo que normalmente se denomina la fase de la acción;

d) el aspecto en el sentido estrecho, lo que normalmente se denomina aspecto verbal y expresa cómo el hablante ve la acción, desde qué punto de vista o perspectiva la observa (abarca la acción en su totalidad, globalmente o parcialmente, abarca una parte de la acción sin interesarle el inicio y el final).

El aspecto verbal en las lenguas eslavas, y por lo tanto también en esloveno, es una categoría morfológica y un rasgo típico. En esloveno se expresa con la oposición binaria: aspecto perfectivo - aspecto imperfectivo que abarca a todos los verbos en cualquier forma, es decir, la marca del aspecto aparece ya en el infinitivo del verbo (priti/prihajati-venir/estar viniendo). En español el concepto de aspecto se expresa de manera diferente, la aspectualidad no se indica con formas morfológicas especiales sino que se usan otros recursos lingüísticos para expresarlo, es decir, no hay un sistema especial para expresar los valores aspectuales sino que éstos se señalan con las formas verbales que normalmente se usan para expresar otros valores (temporales, modales). El entrelazamiento de diferentes valores, el recubrimiento de valores estrictamente aspectuales (vistos desde el punto de vista eslavo) y de los modos de acción no permiten la simple transposición de la definición del aspecto verbal esloveno (eslavo), denominado glagolski vid, a las lenguas romances en general y al español en especial.

En español los valores aspectuales se pueden expresar:

- gramaticalmente (oposiciones entre algunos paradigmas verbales como por ejemplo la oposición entre el pretérito simple y el pretérito imperfecto, entre el pretérito simple y el pretérito compuesto, etc.),

- sintácticamente (el uso de determinantes, el uso del singular o plural, la negación, etc.),

- lexicalmente (el significado perfectivo o imperfectivo inherente de algunos verbos como nacer, abrir, dormir, saltar, pensar),

- lexical y gramaticalmente (perífrasis verbales, algunos verbos pronominales y no pronominales como dormir-dormirse, ir-irse, algunos verbos con prefijos y sufijos como construir-reconstruir, picar-picotear, durar-perdurar, leer-releer).

Además de las formas verbales mencionadas la aspectualidad se indica también con otros recursos lingüísticos: adjetivos, participios, adverbios $^{6}$, formas impersonales del verbo, la voz pasiva, el infinitivo substantivado. ${ }^{7}$

\footnotetext{
6 Véase Ignacio Bosque (1990).

7 Véase Elena de Miguel Aparicio (1992, 1996).
} 
Los gramáticos y lingüistas españoles e hispanoamericanos del pasado normalmente no se dedicaron al estudio especializado de este fenómeno, muchos lo intuyeron o simplemente trasladaron los conceptos de aspecto de las lenguas eslavas al español. Pero una lectura detenida de la gramática de $\mathrm{Nebrija}^{8}$ nos lleva a concluir que el primer gramático de la lengua española intuyó la existencia del aspecto verbal en español sin mencionarlo explícitamente. En la clasificación de los tiempos verbales del pasado distingue el pretérito simple del pretérito imperfecto denominándolos passado acabado y passado no acabado y demuestra de esta manera que la distinción entre los dos tiempos verbales no es temporal sino de otra índole. Otro gran gramático de la lengua española Andrés Bello ${ }^{9}$ también es consciente de la existencia de valores aspectuales pero tampoco menciona explícitamente el aspecto verbal. Es importante su división de los verbos españoles según el significado inherente en verbos desinentes (cuyo significado incluye el término de la acción) y verbos permanentes (cuyo significado expresa duración sin final expresado). Esta distinción de Bello permaneció en las gramáticas españolas hasta nuestros días. Otro aporte importante de Bello a los estudios aspectológicos del español es la oposición que el gramático venezolano observa entre el ante-presente y el pretérito y el copretérito y el pretérito. ${ }^{10}$ Entre los lingüistas que se dedicaron al estudio del aspecto verbal en español hay que destacar a Alarcos Llorach. En su opinión la oposición imperfecto : pretérito simple es una oposición entre un proceso sin término y un proceso con término. También observa oposiciones aspectuales entre las formas no verbales del verbo y los verbos ser y estar. Actualmente los lingüistas españoles e hispanoamericanos prestan mayor atención al problema del aspecto verbal, así se han llevado a cabo algunas investigaciones sobre el tema: Guillermo Rojo (1988), César Hernández Alonso (1986), Ignacio Bosque (1990), Elena de Miguel Aparicio (1992), Graciela Reyes (1990 I, II, III) y otros. ${ }^{11}$

\section{La aspectualidad en la narrativa de Gabriel García Márquez}

\subsection{Algunos paradigmas verbales indicadores de valores aspectuales}

Aunque el hablante puede expresar la aspectualidad con otros paradigmas y otros recursos lingüísticos este capítulo se centra en los paradigmas verbales ${ }^{12}$ de la esfera del pasado y en las oposiciones aspectuales más relevantes.

\footnotetext{
8 Nebrija, 1989, p. 35-36 y p. 250-258.

9 Bello, 1988, p. 433.

10 Bello, 1988, p. 431-479.
}

11 Los hispanistas y romanistas extranjeros se interesaron mucho más por el problema del aspecto verbal, cabe mencionar a R. K. Spaulding, H. Keniston, J. Larochette, K. Togeby, W. E. Bull, J. Černy, J. Slawomirski, E. Coseriu, W. Dietrich ...

12 El término paradigma verbal abarca el concepto que tradicionalmente se indica con el término tiempo verbal. Se prefiere el primer término para evitar la confusión con el concepto de tiempo y para indicar que el paradigma verbal no solamente sirve para expresar valores temporales sino también, como se ve a lo largo de este estudio, otros valores como los aspectuales, los modales, etc. 


\subsubsection{Pretérito simple/pretérito compuesto ${ }^{13}$}

Con el pretérito simple y el pretérito compuesto se señalan tanto la temporalidad como la aspectualidad. En lo que a la temporalidad se refiere los dos paradigmas pertenecen a la serie básica de paradigmas y se prestan para indicar la anterioridad en relación al presente del hablante. El pretérito simple es también el paradigma verbal central de la serie del pasado. ${ }^{14}$

Normalmente la oposición entre el pretérito simple y el pretérito compuesto es una oposición temporal, el pretérito compuesto señala acciones que están temporalmente cerca del momento del habla (es el antepresente de Bello), el pretérito simple señala acciones realizadas en un lapso de tiempo que no tiene ninguna relación con el presente del hablante. En la norma peninsular es ésta la principal oposición. El vínculo del pretérito compuesto con el presente del hablante puede ser cronológico o sentimental, es decir, depende de cómo el hablante siente esta relación con su presente. El pretérito simple está alejado del momento de habla y normalmente va acompañado de complementos circunstanciales de tiempo que delimitan claramente el pasado alejado del presente del hablante.

En la norma del español de América esta oposición temporal está neutralizada. El pretérito simple se usa tanto para señalar acciones alejadas del presente del hablante como también acciones vinculadas con el presente del hablante. La oposición temporal ya casi no existe. Lo que no quiere decir que el pretérito compuesto haya desaparecido del español de América. El análisis del corpus nos ha llevado a la conclusión de que el pretérito compuesto se usa para expresar otros valores, predominantemente aspectuales. Por una parte, se usa para señalar la consecuencia, el resultado de una acción pasada en el presente del hablante (valor que normalmente se expresa en español con la perífrasis verbal tener + participio), por otra parte, se usa para señalar la duración de la acción ocurrida en el pasado en relación al momento del habla pero que dura en el presente, es decir, una acción que ha comenzado en el pasado, sigue en el presente del hablante y es posible que siga en el futuro. ${ }^{15}$ Pero hay

13 Se usan estos términos en lugar de las denominaciones tradicionales de pretérito indefinido y pretérito perfecto, para caracterizar estas dos formas verbales por su forma y no por su contenido. Coincidimos con la opinión de M. Skubic que respecto a este tema dice: Con el fin de demarcar las concepciones de la forma y del contenido denominaré con el nombre de pretérito simple las formas "hice", etc., y con el del pretérito compuesto las formas "he hecho", etc. (Skubic, 1969, p. 1891). Il n'est pas á espérer que la nomenclature des paradigmes verbaux puisse devenir uniforme, sauf si l'on se met d'accord pour employer des termes absolument arbitraires qui n"évoqueraient point le contenu, et porteraient exclusivement sur la forme. (op. cit., 1978, p. 147)

14 Los conceptos de serie básica y serie del pasado son de T. Miklic (Miklič, 1994/I, p. 88, y 1994/II, p. 13). Son constelaciones de paradigmas verbales especializados. La serie básica tiene como paradigma central el presente, que se refiere a las acciones paralelas o simultáneas; el pretérito compuesto y el pretérito simple se refieren a diferentes grados de anterioridad; el futuro simple y el futuro compuesto a diferentes grados de posterioridad. La serie básica tiene un amplio campo de usos ya que se puede usar para cualquier esfera temporal (presente actual, presente habitual, futuro, pasado - presente histórico, extratemporalidad). La serie del pasado tiene como paradigma central el pretérito simple, el imperfecto para la simultaneidad, el pluscuamperfecto y el antepretérito para la anterioridad y el condicional simple y el condicional compuesto para la posterioridad. A las dos series pertenecen también los paradigmas indicadores de la modalidad.

15 Autores como Lope Blanch (1961), Berschin (1975), Harris (1982) observan la misma tendencia de esta oposición en el español de México y de Colombia. 
que admitir que a veces es difícil afirmar rotundamente que el valor expresado con este paradigma verbal en un determinado contexto es únicamente aspectual, ya que a veces también se puede detectar el valor temporal de la norma peninsular (pasado reciente). El pretérito compuesto aparece muy pocas veces en los textos analizados. Ello se debe a que la mayoría de los textos son de carácter narrativo donde prevalece la serie de paradigmas para el pasado y también al hecho de que se trata de textos escritos en el español de América (Colombia) donde la oposición temporal entre los dos paradigmas desapareció y, por lo tanto, el pretérito simple ocupa el lugar del pretérito compuesto también en aquellas partes del texto que incluyen otros discursos (discurso directo).

De acuerdo con los textos analizados el pretérito compuesto se usa sobre todo en el discurso incluido (discurso directo) en el texto cuando se desea subrayar la consecuencia de una acción pasada o la continuación de una acción pasada en el presente o el futuro del hablante; con el pretérito simple se expresa una acción terminada, concluida sin posible continuación en el presente del hablante.

En el ejemplo ATC 64, unos instantes antes de morir el doctor Urbino le dice a Fermina Daza: Sólo Dios sabe cuánto te quise. No dice he querido ni te quiero porque es consciente de que va a morir de un momento a otro, que todo se acabó, que no hay continuación. Con este paradigma verbal (pretérito simple) se expresa una acción inminente (también con la expresión ya muerto en vida), proyectada hacia adelante en el tiempo y presentada como ya terminada. En esta simple enunciación, con el pretérito simple, se expresa lo trágico de la condición humana.

[...] Tiró la cuchara de probar y trató de correr como pudo con el peso invencible de su edad, gritando como una loca sin saber todavía lo que pasaba bajo las frondas del mango, y el corazón le saltó en astillas cuando vio a su hombre tendido bocarriba en el lodo, ya muerto en vida, pero resistiéndose todavía un último minuto al coletazo final de la muerte para que ella tuviera tiempo de llegar. Alcanzó a reconocerla en el tumulto a través de las lágrimas del dolor irrepetible de morirse sin ella, y la miró por última vez para siempre jamás con los ojos más luminosos, más tristes y más agradecidos que ella no le vio nunca en medio siglo de vida en común, y alcanzó a decirle con el último aliento:

- Sólo Dios sabe cuánto te quise. (ATC, 64)

En el ejemplo CMA 17 con el pretérito compuesto se señala una acción abierta. El hablante deja abierta la posibilidad de que vuelva a nacer un hombre semejante. Si hubiera usado el pretérito simple (No volvió a nacer otro hombre como ese), esa posibilidad no existiría. El hablante la relegaría al pasado. El pretérito compuesto señala valores aspectuales y temporales, con la perífrasis verbal volver $a+$ inf. se añade un valor aspectual de iteración. Divina Flor, que era hija de un marido más reciente, se sabia destinada a la cama furtiva de Santiago Nasar, y esa idea le causaba una ansiedad prematura. "No ha vuelto a nacer otro hombre como ese", me dijo, gorda y mustia, y rodeada por los hijos de otros amores. (CMA, 17) 
Los verbos introductorios en los ejemplos CMA 26-27 y CMA 27 se usan en dos paradigmas verbales distintos, pero se encuentran en dos contextos iguales que no están en oposición temporal. Ambos hacen parte de la esfera del pasado, ambos señalan acciones terminadas en el pasado (en el período anterior al presente del hablante) y la perspectiva del narrador es igual en los dos casos. El uso del pretérito compuesto en este contexto es inusual, por lo tanto la forma ha dicho indica el resultado de la acción de decir que se traslada al presente del narrador de CMA: la hermana le ha dicho algo y ahora está dicho y anotado. Dijo sugiere una acción única y concluida.

En la baranda superior, junto al camarote del capitán, iba el obispo de sotana blanca con su séquito de españoles. "Estaba haciendo un tiempo de Navidad", ha dicho mi hermana Margot. Lo que pasó según ella, fue que el silbato del buque soltó un chorro de vapor a presión al pasar frente al puerto, y dejó ensopados a los que estaban más cerca de la orilla. (CMA, 26-27)

Mi hermana Margot, que estaba con él en el muelle, lo encontró de muy buen humor y con ánimos de seguir la fiesta, a pesar de que las aspirinas no le habían causado ningún alivio. "No parecia resfriado, sólo estaba pensando en lo que habia costado la boda", me dijo. (CMA, 27)

En los ejemplos CMA 37 y CMA 44 el pretérito compuesto se usa en el discurso directo y hace parte de la serie básica de paradigmas verbales. Señala el valor temporal de anterioridad en relación al momento de habla, o escritura de la carta. La acción no está alejada temporalmente, se acerca al presente del narrador (he visto, ha venido) y las consecuencias de la acción se hacen sentir en el marco temporal que abarca el presente del narrador (valor aspectual de consecuencia de una acción pasada en el presente del hablante). En el ejemplo CMA 44 la educación pasada de las jóvenes tiene como consecuencia el hecho de que ahora saben sufrir. En el ejemplo CMA 37 un hombre raro está ahora en el pueblo como consecuencia de su llegada/venida.

Mi madre me escribió al colegio a fines de agosto y me decía en una nota casual: " $\underline{\mathrm{Ha}}$ venido un hombre muy raro". En la carta siguiente me decía: "El hombre raro se llama Bayardo San Román, y todo el mundo dice que es encantador, pero yo no lo he visto". (CMA, 37)

"Cualquier hombre será feliz con ellas, porque han sido criadas para sufrir". (CMA, 44)

Con la oposición temporo-aspectual entre el pretérito compuesto y el pretérito simple se puede señalar el cambio de perspectiva del narrador. El autor usa este juego de paradigmas para cambiar la perspectiva del narrador en algunos momentos del Relato de un náufrago y principalmente en la Crónica de una muerte anunciada y en La hojarasca. 
El narrador cuenta la historia desde una determinada perspectiva, escoge un punto de mira, un ángulo de enfoque y desde allí percibe y narra los acontecimientos. ${ }^{16}$ Los cambios de focalización, del punto de mira, están relacionados con el cambio del tipo de narrador. El narrador puede ser exterior, anónimo y omnisciente ${ }^{17} \mathrm{y}$ los acontecimientos que narra ganan en objetividad, se trata del clásico relato en tercera persona. Pero el narrador puede ser un narrador interno (focalizador interno según Mieke Bal) que participa de los acontecimientos narrados y narra en primera persona. El narrador interno puede ser narrador protagonista $o$ narrador testigo. ${ }^{18}$

En el caso del Relato de un náufrago $(\mathrm{RN})$ el narrador (el náufrago que sobrevivió diez días a la deriva en una balsa) es al mismo tiempo narrador protagonista y narrador testigo, ya que es él el que narra en primera persona los acontecimientos de los que fue partícipe. Sin embargo, el mismo autor participa del relato como transcriptor de los hechos contados y como introductor a la historia (la introducción está en tercera persona). El cambio de paradigma (pretérito simple - pretérito compuesto) puede ser la señal de un cambio en la perspectiva del narrador. Así lo demuestra el ejemplo RN 52. Con el pretérito compuesto he leído el narrador expresa el estado proveniente de una acción pasada. Con el pretérito simple leí indica una acción pasada concluida. En lugar del pretérito compuesto el narrador hubiera podido usar el presente del verbo recordar en forma negativa (no recuerdo) para expresar el mismo valor (he olvidado y ahora no recuerdo). El verbo olvidar, perfectivo por su valor léxico inherente, expresa en el pretérito compuesto un estado que abarca el momento del habla del hablante. ${ }^{19}$

${ }^{16}$ Este procedimiento se denomina en narratologia focalización.

Narrative fiction (...) operates a division between a real speaker (the author) and a fictional surrogate inside the text (the narrator). The former, like a historian, always "makes himself absent", while the latter frequently injects subjectivity into linguistic structure. (Fleischman, 1990, p. 118)

Me referiré con el término focalización a las relaciones entre los elementos presentados y la concepción a través de la cual se presentan. (Bal, 1987, p.108)

17 Mieke Bal (1987, p. 110-111) usa el término de focalizador externo; también se le denomina narrador omnisciente. Vargas Llosa (1971, p. 109-111) habla del narrador como suplantador de Dios.

${ }^{18}$ Este punto de mira o ángulo de enfoque, esta adopción de una perspectiva determinada para ordenar un mundo, cobra en la novela dos modos fundamentales:

1. El narrador está fuera de los acontecimientos narrados: refiere los hechos sin ninguna alusión a si mismo. (Es el clásico relato en tercera persona).

2. El narrador participa en los acontecimientos narrados. Dicha participación puede asumir: a) un papel protagónico; b) un papel secundario; c) el papel de mero testigo presencial de los hechos. En estos casos, el narrador se identifica con el personaje. Es el relato en que el narrador se sitúa, habla de sí en primera persona. (Tacca, 1985, p. 65)

Aqui empleo los conceptos de narrador testigo y narrador protagonista para distinguir el yo como testigo y el yo como protagonista (González Boixo, 1983, p. 126). G. Reyes los denomina narrador del narrador y narrador personaje. (Reyes, 1983, p. 57)

${ }^{19}$ Muchos perfectos de verbos perfectivos equivalen a presentes negados de verbos imperfectivos. Esta parece ser una particularidad bastante extendida en el sistema temporal de nuestra lengua. Decimos "He olvidado el resto" (perfecto) o "No recuerdo el resto" (presente) con casi absoluta equivalencia. Empleamos "Se ha ido" (perfecto) y "No está aqui" (presente) en situaciones muy similares. Ello muestra que el perfecto se aproxima en su naturaleza aspectual al presente, o al menos denota una significación similar. Además la negación de un verbo perfectivo produce como resultado un significado imperfectivo. (Femández Ramirez, 1986, p. 252) 
Se produce un cambio de perspectiva del narrador, los dos paradigmas verbales en cuestión se encuentran aquí en oposición aspectual y temporal: la esfera del presente del narrador testigo (he olvidado) : la esfera del pasado del narrador protagonista (lei).

En Mobile, en una revista cuyo nombre he olvidado lei el relato de un náufrago que fue devorado por los antropófagos. Pero no era en ese relato en lo que pensaba. (RN, 52)

En el ejemplo RN 109 los paradigmas verbales señalan también el cambio de perspectiva del narrador: las acciones en pretérito compuesto y en presente se refieren al narrador testigo mientras que las acciones en pretérito simple se refieren al narrador protagonista. Los paradigmas verbales del fragmento pertenecen a la serie básica; en el centro está el presente tiene, dicen, es, pregunto. He contado y conté son anteriores en relación al momento del habla (el presente del hablante) y se encuentran en oposición aspectual. He contado expresa que el hablante/narrador testigo seguirá contando su historia en la televisión y a sus amigos, la acción permanece abierta con posibilidades de continuación en el presente y en el futuro del hablante. Con conté el hablante/narrador protagonista expresa que ya contó su historia a la viuda y no hay más posibilidades de volver a hacerlo, la acción está concluida. Hice significa que la acción terminó en el pasado y no continúa en el presente del hablante/narrador protagonista: los diez días de lucha por la vida en el mar ya pasaron.

He contado mi historia en la televisión y a través de un programa de radio. Además, se la he contado a mis amigos. Se la conté a una anciana que tiene un voluminoso album de fotografias y que me invitó a su casa. Algunas personas me dicen que esta historia es una invención fantástica. Yo les pregunto: "Entonces, ¿qué hice durante mis diez días en el mar?" (RN, 109)

La Crónica de una muerte anunciada está narrada en primera persona. Por una parte el narrador investiga las circunstancias del asesinato de Santiago Nasar y actúa como cronista y narrador testigo. Busca datos fidedignos del asesinato y desea actuar como investigador objetivo. Por otra parte, él mismo estuvo involucrado en los acontecimientos de hace veintisiete años, de aquel lunes de febrero cuando ocurrió la tragedia y, por lo tanto, actúa también como narrador protagonista. El narrador va cambiando de perspectiva. A veces es protagonista de la historia y la narra desde ese punto de vista, a veces "sale" de la historia y observa los acontecimientos desde fuera, los describe como cronista, los enfoca en su totalidad. Por eso, ya en el comienzo de la novela, se presenta como un observador externo, conocedor de la situación y de los acontecimientos y hace conocer toda la historia en las primeras páginas. En la primera frase (CMA 9a) la perspectiva del narrador testigo es igual a la de un narrador omnisciente que presenta los acontecimientos pasados globalmente en pretérito simple (se levantó) y los anticipa (perífrasis verbal: iban a matar). Pero en la tercera frase (CMA 9b) aparece un pronombre personal de primera persona de singular $(m e)$ que indica que el narrador no es omnisciente sino que está dentro de la narración. 
El día en que lo iban a matar, Santiago Nasar se levantó a las 5:30 de la mañana para esperar el buque en que llegaba el obispo. (CMA, 9a)

"Siempre soñaba con árboles", me dijo Plácida Linero, su madre, evocando 27 años después los pormenores de aquel lunes ingrato. (CMA, 9b)

El punto de partida es el presente del narrador y su visión de los acontecimientos pasados. Los paradigmas verbales pertenecen a la serie del pasado ya que se trata de una visión retrospectiva, del recuerdo de acciones pasadas. Los paradigmas verbales de la serie básica aparecen en los discursos directos incorporados en el texto ${ }^{20}$ y cuando se produce el cambio de la perspectiva del narrador, cuando el narrador testigo se transforma en el narrador protagonista.

En el ejemplo CMA 57-58 el narrador es al mismo tiempo aquel que narra la historia (narrador testigo) y aquel que actúa en la historia (narrador protagonista). El pretérito compuesto se encuentra en un entorno de paradigmas verbales narrativos para la esfera del pasado e indica el cambio de perspectiva del narrador. Se trata de un salto de la esfera del pasado del narrador a la esfera del presente del narrador que incluye el momento del habla/de la escritura. Yo estuve con él se refiere al narrador protagonista, he tenido que repetir al narrador testigo (cronista que en ese momento escribe la crónica).

Tampoco se supo nunca con qué cartas jugó Santiago Nasar. Yo estuve con él todo el tiempo, en la iglesia y en la fiesta, junto con Cristo Bedoya y mi hermano Luis Enrique, y ninguno de nosotros vislumbró el menor cambio en su modo de ser. He tenido que repetir esto muchas veces, pues los cuatro habiamos crecido juntos en la escuela y luego en la misma pandilla de vacaciones y nadie podía creer que tuviéramos un secreto sin compartir, $y$ menos un secreto tan grande. (CMA, 57-58)

La Hojarasca es la única de las novelas y relatos analizados donde el autor usa el pretérito compuesto con más frecuencia. Tres monólogos interiores componen la novela, se expresan tres imágenes subjetivas de una misma realidad. La Hojarasca es como una imagen visual, un momento capturado en su inmovilidad. El lugar y el tiempo de la narración están minuciosamente definidos. El lugar: una pieza cerrada, sofocante donde yace un muerto. El tiempo: de las dos a las dos y media de la tarde del miércoles, 12 de septiembre de 1928. Tres personas que velan el cadáver expresan la realidad que perciben en su entorno y dejan divagar sus pensamientos por los vericuetos de su pasado y presente. Las percepciones del espacio, de la gente, de los objetos y de los acontecimientos en el momento cuando los protagonistas piensan se expresan en los paradigmas verbales de la serie básica. El pretérito simple y el pretérito compuesto se encuentran en oposición aspectual. En el ejemplo LH 45 con el pretérito compuesto se señala la consecuencia presente (en relación al narrador) de los actos pasados mientras que con el pretérito simple se indican acciones concluidas en un

20 Véase los ejemplos mencionados CMA 17, CMA 26-27, CMA 27, CMA 44. 
pasado reciente o lejano del narrador: la cara del muerto provocó una impresión tan fuerte que el niño la sigue viendo (he retenido, veo). El abuelo se ha sentado junto a la madre $\mathrm{y}$ sigue sentado. Pero hace solo un momento regresó del cuarto vecino y rodó la silla.

Ahora el ataúd está cerrado, pero yo recuerdo la cara del muerto. La he retenido con tanta precisión que si miro hacia la pared veo los ojos abiertos, las mejillas estiradas y grises como la tierra húmeda, la lengua mordida a un lado de la boca. Esto me produce una ardorosa sensación de intranquilidad. Tal vez el pantalón no deje de apretarme nunca a un lado de la pierna.

Mi abuelo se ha sentado junto a mi madre. Cuando regresó del cuarto vecino rodó la silla y ahora permanece aquí, sentado junto a ella, sin decir nada, la barba apoyada en el bastón y estirada hacia adelante la pierna coja. Mi abuelo espera. Mi madre, como él, espera. Los hombres que han dejado de fumar en la cama y permanecen quietos, ordenados, sin mirar el ataúd, ellos también esperan. (LH, 45)

En el ejemplo LH 11 las acciones estrechamente relacionadas con el momento de la percepción se expresan con el pretérito compuesto. Las acciones realizadas momentos antes de la narración están en pretérito simple. El autor juega con los dos paradigmas, alejando y acercando las acciones, como imágenes móviles que cambian con el pasar de los segundos y minutos, que son como el fluir del pensamiento. Lo que en este momento es presente, el momento siguiente ya será pasado: no ha venido, hemos venido, han traido, han vaciado son acciones (en pretérito compuesto) que tienen que ver con el momento del habla (del monólogo). Unos segundos después ya son pasado y están en pretérito simple (quedó, sacudió, cayeron). En ese instante el presente es el momento de levantar el muerto: el niño observa cómo está vestido el difunto.

No sé por qué no ha venido nadie al entierro. Hemos venido mi abuelo, mamá y los cuatro guajiros que trabajan para mi abuelo. Los hombres han traido una bolsa de cal y la han vaciado dentro del ataüd. Si mi madre no estuviera tan extraña y distraida, le preguntaria por qué hacen eso. No entiendo por qué tienen que regar cal dentro de la caja. Cuando la bolsa quedó vacía, uno de los hombres la sacudió sobre el ataúd y todavia cayeron unas últimas virutas, más parecidas al aserín que a la cal. Han levantado al muerto por los hombros y los pies. Tiene un pantalón ordinario, sujeto a la cintura por una correa ancha y negra, y una camisa gris. ( $\mathrm{LH}, 11)$

\subsubsection{Pretérito simple/pretérito imperfecto}

La oposición entre el pretérito simple y el pretérito imperfecto es la oposición aspectual más conocida y estudiada. Los dos paradigmas verbales son principalmente parte de la serie de paradigmas para la esfera del pasado, el hablante los usa para expresar acciones pasadas que se diferencian entre sí porque indican distintos valores aspectuales. Son también los dos típicos tiempos verbales de la narración. 
El pretérito simple se define en este estudio como el paradigma verbal que se usa para señalar las acciones pasadas de una manera global, compleja, incluyendo el inicio y el final de la acción. Las acciones son vistas desde el punto de referencia que coincide con el momento del habla y se abarcan en su totalidad. Con verbos de significado inherente perfectivo el pretérito simple expresa acciones puntuales, con verbos cuyo significado inherente es imperfectivo se expresan acciones durativas perfectivas que se pueden definir temporalmente con complementos de tiempo. En los textos narrativos el pretérito simple es un típico paradigma verbal para la narración. Puesto que con este paradigma se expresan acciones vistas en su totalidad, se presta a expresar la sucesión de acciones y el avance de la narración.

Entre todos los paradigmas verbales es el imperfecto el que tiene la mayor cantidad de valores temporales, aspectuales y modales. El hablante expresa con este paradigma que la acción es anterior al momento del habla pero presenta la acción en su desarrollo, abierta, sin límites (el inicio y el final no se definen). Con los verbos cuyo valor inherente es el perfectivo el imperfecto se usa para indicar acciones reiterativas (imperfecto iterativo o cíclico) $o$ para expresar una habitud (imperfecto habitual). Con verbos cuyo valor léxico inherente es imperfectivo el imperfecto acentúa la duración de la acción, describe la situación, las circunstancias (imperfecto de situación y de descripción). Con el imperfecto el hablante expresa acciones simultáneas a otras acciones del pasado, es decir, acciones en curso a las que se incorporan otras acciones vistas globalmente o no.

El hablante observa la acción de diferentes maneras. Con el imperfecto ilumina una porción de la acción y no abarca ni el inicio ni el final. La acción queda abierta, presentada en su curso. Esta perspectiva se denomina perspectiva cursiva. Con el pretérito simple el hablante abarca toda la acción incluyendo el inicio y el final, la acción es cerrada, presentada en su totalidad: inicio, decurso, final. Esta perspectiva se denomina perspectiva global o compleja. Con el pretérito simple el hablante se encuentra en el punto de referencia que coincide con el momento del habla y desde allí observa la acción pasada globalmente. Con el imperfecto el hablante se "desplaza" a otro punto de observación, un punto escogido del pasado y desde allí observa la acción como una nueva actualidad. ${ }^{21}$ De esta oposición básica descrita se desprenden todos los usos de los dos paradigmas verbales.

\subsubsection{Cambios de perspectiva}

Los cambios de perspectiva (cursiva - global) son un recurso estilístico usado con frecuencia en los textos narrativos de Gabriel García Márquez. En el ejemplo ATC 411 se señala, con el imperfecto, una acción habitual en la esfera del pasado: Fermina Daza aplazaba cada año la quemazón de ropa vieja. El verbo está en imperfecto, la perspectiva es cursiva. Pero en seguida hay un cambio repentino de perspectiva de la misma acción. El narrador toma distancia y observa la acción globalmente (la misma acción se presenta en pretérito

21 Miklič, 1981, p. 68-69. 
simple: se aplazó), continúa indicando la habitud pero la acción se presenta como terminada. Siguen de nuevo acciones habituales en perspectiva cursiva (hacian, empezaban a llenarse, vivian, iban a morir).

Así que la quemazón se aplazaba se aplazó siempre, y las cosas no hacian sino cambiar de lugar, de sus sitios de privilegio a las antiguas caballerizas transformadas en depósitos de saldos, mientras los espacios liberados, tal como él lo decía, empezaban a llenarse de nuevo, a desbordarse de cosas que vivian un instante y se iban a morir en los roperos: hasta la siguiente quemazón. (ATC, 411)

Algo semejante ocurre en el ejemplo ATC 412 donde cambia el punto de mira del narrador. Las acciones en imperfecto (parecia, aproximaba, se sentía, era) se presentan en su transcurrir, el narrador se acerca a Fermina Daza y lee sus pensamientos. El foco se encuentra en el centro de la acción. Con el pretérito simple el narrador se aleja y observa las acciones desde fuera como un narrador omnisciente que conoce la historia y puede iluminar las acciones globalmente (fue, ayudaron, fueron, permitió). En la última frase del fragmento se presenta, con el pretérito simple (fue), una acción terminada y temporalmente definida, $\mathrm{y}$, con el imperfecto estaba, se indica una acción simultánea, durativa.

Le parecia inconcebible, pero a medida que se aproximaba el primer aniversario de la muerte del esposo, Fermina Daza se sentia entrando en un ámbito sombreado, fresco, silencioso: la floresta de lo irremediable. No era muy consciente todavia, ni lo fue en varios años, de cuánto la avudaron a recobrar la paz del espíritu las meditaciones escritas. Fueron ellas, aplicadas a sus experiencias, lo que le permitió entender su propia vida, y a esperar con serenidad los designios de la vejez. El encuentro en la misa de conmemoración fue una ocasión providencial de darle a entender a Florentino Ariza que también ella, gracias a sus cartas de aliento, estaba dispuesta a borrar el pasado. (ATC, 412)

En el ejemplo ATC 16 se indican con el imperfecto acciones habituales del dr. Urbino (tenía, se levantaba, empezaba a tomar, tomaba, llevaba, aspiraba). La perspectiva cambia cuando el narrador centra su mirada en las acciones terminadas en un tiempo definido ya terminado (quedaron, logró). Con fue la perspectiva es global y se refiere a toda la vida del médico en el marco de la cual él tenía determinadas habitudes que el narrador presenta en perspectiva cursiva. Permanecía una hora es parte de la rutina de la vida del dr. Urbino y está en perspectiva cursiva, con dictó el narrador acentúa la perfección de la acción que está limitada temporalmente a la vida del doctor aunque dentro del mismo lapso de tiempo la clase en la escuela de medicina es un trabajo regular y parte de la rutina. Con los cambios de perspectivas el narrador juega con el tiempo iluminando las acciones desde diferentes puntos de mira.

El doctor Juvenal Urbino tenía una rutina fácil de seguir, desde que quedaron atrás los años tormentosos de las primeras armas, y logró una respetabilidad y un prestigio que no tenían igual en la provincia. Se levantaba con los primeros gallos, y a esa hora em- 
pezaba a tomar sus medicinas secretas [...]. Tomaba algo a cada hora, siempre a escondidas, porque en su larga vida de médico y maestro fue siempre contrario a recetar paliativos para la vejez: le era más fácil soportar los dolores ajenos que los propios. En el bolsillo llevaba siempre una almohadilla de alcanfor que aspiraba a fondo cuando nadie lo estaba viendo para quitarse el miedo de tantas medicinas revueltas.

Permanecía una hora en su estudio, preparando la clase de clinica general que dictó en la escuela de Medicina todos los días de lunes a sábado, a las ocho en punto, hasta la vispera de su muerte. (ATC, 16)

Las introducciones del discurso directo (ATC 329, ATC 425) y del discurso indirecto (ATC 34-35, ATC 126-127, ATC 425) en el texto narrativo interrumpen el flujo de la narración. Las narraciones de los protagonistas de la novela complementan el relato del narrador (relatos dentro del relato). Los verbos introductorios se encuentran en las dos perspectivas. Con el pretérito simple las acciones son presentadas como perfectivas y puntuales, con el imperfecto se presentan como repetitivas.

- ¿Qué es lo que pasa? - preguntó.

- Tú lo sabes mejor que yo-dijo ella. (ATC, 329)

Le habia dicho además que a menudo, cuando ella salia de la escuela, pasaba muchas horas con Tránsito Ariza haciendo prodigios de bordado en la mercería, pues era una maestra notable, y que si no habia seguido viendo a Florentino Ariza con la misma frecuencia no había sido por su gusto sino por la divergencia de sus vidas.

Antes de llegar a fondo de sus propósitos el doctor Urbino Daza hizo algunas divagaciones sobre la vejez. Pensaba que el mundo iria más rápido sin el estorbo de los ancianos. Dijo: "La humanidad, como los ejércitos en campaña, avanza a la velocidad del más lento". (ATC, 425)

El doctor Urbino se resistía a admitir que odiaba a los animales, y lo disimulaba con toda clase de fábulas cientificas y pretextos filosóficos que convencian a muchos, pero no a su esposa. Decia que quienes lo amaban en exceso eran capaces de las peores crueldades con los seres humanos. Decía que los perros no eran fieles sino serviles, que los gatos eran oportunistas y traidores, que los pavorreales eran heraldos de la muerte, que las guacamayas no eran más que estorbos ornamentales, que los conejos fomentaban la codicia, que los micos contagiaban la fiebre de la lujuria y que los gallos estaban malditos porque se habian prestado para que a Cristo lo negaran tres veces. (ATC, 34-35)

Euclides, uno de los niños nadadores, se alborotó tanto como él con la idea de una exploración submarina, después de conversar no más de diez minutos. Florentino Ariza no le reveló la verdad de su empresa sino que se informó a fondo sobre sus facultades de buzo y navegante. Le preguntó si podría descender sin aire a veinte metros de profundidad, y 
Euclides dijo que sí. Le preguntó si estaba en condiciones de llevar él solo un cayuco de pescado por la mar abierta en medio de una borrasca, sin más instrumentos que su instinto, y Euclides dijo que sí. Le preguntó si sería capaz de localizar un lugar exacto a dieciséis millas náuticas al noroeste de la isla mayor del archipiélago de Sotavento, y Euclides dijo que sí. Le preguntó si era capaz de navegar de noche orientándose por las estrellas, y Euclides le dijo que sí. Le preguntó si estaba dispuesto a hacerlo por el mismo jornal que le pagaban los pescadores por ayudarlos a pescar, y Euclides le dijo que sí, pero con un recargo de cinco reales los domingos. Le preguntó si sabía defenderse de los tiburones, y Euclides le dijo que si, pues tenía artificios mágicos para espantarlos. Le preguntó si era capaz de guardar un secreto aunque lo pusieran en las máquinas de tormentos del Palacio de la Inquisición, y Euclides dijo que si, pues a nada le decia que no, y sabía decirlo con tanta propiedad que no habia modo de ponerlo en duda. (ATC, 126-127)

\subsubsection{El relieve}

En los textos narrativos estudiados los dos paradigmas se usan para la puesta de relieve 22 de las acciones, es decir, para señalar el primer y el segundo plano. Ello depende de la voluntad del hablante/narrador para realzar unas acciones y desplazar otras al margen. La puesta de relieve es un procedimiento estilístico muy frecuente. Con el imperfecto (perspectiva cursiva) se indican las situaciones, los estados, las acciones en curso, las acciones reiterativas que sirven de telón de fondo para las acciones en el primer plano expresadas en perspectiva global (en pretérito simple o pluscuamperfecto). Estas acciones sobresalen, siempre se presentan en su totalidad y se suceden las unas a las otras (CAS 32).

Una tarde se entusiasmaron los muchachos con la estera voladora que pasó veloz al nivel de la ventana del laboratorio llevando al gitano conductor y a varios niños de la aldea que hacian alegres saludos con la mano, y José Arcadio Buendía ni siquiera la miró. (CAS, 32)

El imperfecto sirve para la descripción de la situación, la escena, donde se suceden las acciones en pretérito simple (CAS 36).

José Arcadio tardó mucho tiempo para restablecerse de la perplejidad cuando salió a la calle y vio la muchedumbre. No eran gitanos, eran hombres y mujeres como ellos, de cabellos lacios y piel parda, que hablaban su misma lengua y se lamentaban de los mismos dolores. Traían mulas cargadas de cosas de comer, carretas de bueyes con muebles

22 Ya Alarcos Llorach (1975, p. 13 y 15) habla del relieve y lo relaciona con el aspecto. Para él el relieve es lo mismo que el aspecto (en su opinión se trata de la oposición terminativo : no-terminativo).

De manera que no se trata sólo de dar relieve a la narración separando un primer plano de un plano indiferenciado, continuo, de fondo. Procuramos delimitar, dar un término, destacado, a ciertas sustancias sobre la sustancia de fondo. (Alarcos Llorach, op. cit., 15)

Con la puesta de relieve (mis en relief, grounding) se crea la textura de la narración, algunas acciones (mayoritariamente en pretérito simple) se presentan en el primer plano y otras (mayoritariamente en imperfecto) en el segundo plano (fondo, situación). Véase Fleischman, 1990, p. 168. 
y utensilios domésticos, puros y simples accesorios terrestres puestos en venta sin aspavientos por los mercachifles de la realidad cotidiana. Venían del otro lado de la ciénaga, a sólo dos días de viaje, donde había pueblos que recibian el correo todos los meses y conocían las máquinas del bienestar. (CAS, 36)

Ya que las acciones en imperfecto normalmente se encuentran en el segundo plano coinciden temporalmente con las acciones que se desenvuelven en este marco descrito con el imperfecto. Por eso el imperfecto indica también la simultaneidad en relación a otras acciones en imperfecto, en pretérito simple y en pluscuamperfecto (CAS 33, CAS 105, CAS 126, CAS 167-168).

Mientras se desarrollaba el triste interrogatorio del hombre-víbora, se había abierto paso por entre la multitud hasta la primera fila en que se encontraba la gitana, y se había detenido detrás de ella. (CAS, 33)

El coronel Aureliano Buendia estaba aquella noche terminando el poema del hombre que se había extraviado en la lluvia cuando la muchacha entró al cuarto. (CAS, 105)

Carmelita Montiel, una virgen de veinte años, acababa de bañarse con agua de azahares y estaba regando hojas de romero en la cama de Pilar Ternera, cuando sonó el disparo. (CAS, 126)

Se extravió por desfiladeros de niebla, por tiempos reservados al olvido, por laberintos de desilusión. Atravesó un páramo amarillo donde el eco repetía los pensamientos y la ansiedad provocaba espejismos premonitorios. Al cabo de semanas estériles, llegó a una ciudad desconocida donde todas las campanas tocaban a muerto. (CAS, 167-168)

El cambio en la manera de iluminar las acciones (el claro-oscuro, el hecho de iluminarlas o desplazarlas a la oscuridad), el cambio de plano, se refleja también en el ritmo de la narración. Las acciones del segundo plano vistas en su curso están en imperfecto, en perspectiva cursiva. La progresividad, la duración y/o la repetición se acentúan con las perífrasis verbales (ir(se) + gerundio, soler + infinitivo) y otros medios lingüísticos. La narración se detiene, se bifurca, deambula por otros caminos. Se van creando subnarraciones. El ritmo de la narración es más lento. Las acciones iluminadas globalmente llevan la narración hacia adelante, las acciones en pretérito simple se suceden, aceleran y hacen avanzar la narración.

En el capítulo diez y seis de Cien años de soledad, en la página 248, comienza la lluvia. El narrador define detalladamente que la lluvia duró cuatro años, once meses y dos días. La lluvia termina en la página 260 con un marco temporal definido con exactitud. El inicio y el final de la lluvia se presentan en perspectiva global.

Llovió cuatro años, once meses y dos dias. (CAS, 248) 
Un viernes a las dos de la tarde se alumbró el mundo con un sol bobo, bermejo y áspero como polvo de ladrillo, y casi tan fresco como el agua, y no volvió a llover en diez años. (CAS, 260)

La narración se desenvuelve dentro de este marco temporal (el periodo de la lluvia). Las acciones principales que hacen avanzar la narración se presentan en perspectiva global con las acciones en pretérito simple:

El regreso de Aureliano Segundo a la casa de su mujer y su lucha contra las inundaciones:

Para no aburrirse, se entregó a la tarea de componer los numerosos desperfectos de la casa. Ajustó bisagras, aceitó cerraduras, atornilló aldabas y niveló fallebas. Durante varios meses se le vio vagar con una caja de herramientas que debieron olvidar los gitanos en los tiempos de José Arcadio Buendia, y nadie supo si fue por la gimnasia involuntaria, por el tedio invernal o por la abstinencia obligada, que la panza se le fue desinflando poco a poco como un pellejo, y la cara de tortuga beatifica se le hizo menos sanguinea y menos protuberante la papada, hasta que todo él terminó por ser menos paquidérmico y pudo amarrarse otra vez los cordones de los zapatos. (CAS, 248-249)

Los problemas de salud de Fernanda:

Pero la tortuosa costumbre de no llamar las cosas por su nombre la llevó a poner lo anterior en lo posterior, y a sustituir lo parido por lo expulsado, y a cambiar flujos por ardores para que todo fuera menos vergonzoso, de manera que Úrsula concluyó razonablemente que los trastornos no eran uterinos, sino intestinales, y le aconsejó que tomara en ayunas una papeleta de calomel. (CAS, 251)

El entierro de Gerineldo Márquez:

Aparecieron como una visión irreal en la calle que todavía llevaba el nombre del coronel Aureliano Buendía, y todos miraron la casa al pasar, y doblaron la esquina por la plaza, donde tuvieron que pedir ayuda para sacar la carreta atascada. (CAS, 252)

El conflicto entre Fernanda y Aureliano Segundo, su cantaleta y la reacción de su marido: Entonces Aureliano Segundo perdió el dominio. Se incorporó sin prisa, como si sólo pensara estirar los huesos, y con una furia perfectamente regulada y metódica fue agarrando uno tras otro los tiestos de begonias, las macetas de helechos, los potes de orégano, y uno tras otro los fue despedazando contra el suelo. [...] Embriagado por la torrente incontenible del desahogo, Aureliano Segundo rompió el cristal de vidriera, y una por una, sin apresurarse, fue sacando las piezas de la vajilla y las hizo polvo contra el piso. Sistemático, sereno, con la misma parsimonia con la que habia empapelado la casa de billetes, fue rompiendo luego contra las paredes la cristaleria de Bohemia, los floreros pintados a mano, los cuadros de las doncellas en barcas cargadas de rosas, los espejos de 
marcos dorados, y todo cuanto era rompible desde la sala hasta el granero, y terminó con la tinaja de la cocina que se reventó en el centro del patio con una explosión profunda. Luego se lavó las manos, se echó encima el lienzo encerado, y antes de medianoche volvió con unos tiesos colgajos de carne salada, varios sacos de arroz y maíz con gorgojo, y unos desmirriados racimos de plátanos. Desde entonces no volvieron a faltar las cosas de comer. (CAS, 257)

La búsqueda del oro enterrado:

Convencido de que Úrsula se llevaria el secreto a la tumba, Aureliano Segundo contrató una cuadrilla de excavadores con el pretexto de que construyeran canales de desagüe en el patio y en el traspatio y él mismo sondeó el suelo con barretas de hierro y con toda clase de detectores de metales, sin encontrar nada que se pareciera al oro en tres meses de exploraciones exhaustivas. Más tarde recurrió a Pilar Ternera con la esperanza de que las barajas vieran más que los cavadores, pero ella empezó por explicarle que era inútil cualquier tentativa mientras no fuera Úrsula quien cortara el naipe. (CAS, 259-260)

\section{La visita a Petra Cotes:}

Fue una decisión tan inquebrantable, que Aureliano Segundo volvió a su casa ocho meses después del último recado, y la encontró verde, desgreñada, con los párpados hundidos y la piel escarchada por la sarna. [...] (CAS, 261)

Las acciones mencionadas se desenvuelven en el Macondo decadente (CAS 260), con los protagonistas que piensan, sueñan, esperan (CAS 257, CAS 258). El marco a estas acciones son las descripciones (perspectiva cursiva, las acciones están en imperfecto) de la ciudad, de las casas, de la lluvia, de las gentes que envejecen, las cosas que se desintegran: Amaranta Úrsula y el pequeño Aureliano habian de recordar el diluvio como una época feliz. A pesar del rigor de Fernanda, chapaleaban en los pantanos del patio, cazaban lagartos para descuatizarlos y jugaban a envenenar la sopa echándole polvo de alas de mariposas en los descuidos de Santa Sofia de la Piedad. (CAS, 257)

Úrsula era feliz en medio de la parentela irreal que los niños describian sin omisión de detalles, como si de verdad la hubieran conocido. Úrsula conversaba con sus antepasados sobre acontecimientos anteriores a su propia existencia, gozaba con las noticias que le daban y lloraba con ellos por muertos mucho más recientes que los mismos contertulios. (CAS, 258)

Macondo estaba en ruinas. En los pantanos de las calles quedaban muebles despedazados, esqueletos de animales cubiertos de lirios colorados, últimos recuerdos de las hordas de advenedizos que se fugaron de Macondo tan atolondradamente como habian llegado. [...] De la antigua ciudad alambrada sólo quedaban los escombros. Las casas de 
madera, las frescas terrazas donde transcurrian las serenas tardes de naipes, parecian arrasadas por una anticipación del viento profético que años después habia de borrar a Macondo de la faz de la tierra (CAS, 260)

En el Relato de un náufrago (ejemplo RN 45) la misma situación se presenta en las dos perspectivas, la global y la cursiva: me senti y me sentía. El verbo sentir en este caso no cambia de significado al cambiar de valor aspectual. En ambos casos se trata de un estado descrito con dos perspectivas. Ocurre algo semejante en el ejemplo RN 76, en el mismo contexto hay dos perspectivas. Con el pretérito simple las acciones se encuentran en el primer plano y marcan el compás de la narración (me senti abandonado, me aferré, decidí, me sentí acompañado), con el imperfecto las acciones están desplazadas al segundo plano y describen la situación, las circunstancias (era mi segunda noche), indican el estado, los sentimientos, los pensamientos (asombraba, me sentía débil, llevaba sin agua, me sentía acompañado...). Al cambiar el paradigma verbal, cambia el curso de la narración, con el imperfecto el narrador se detiene para pensar, describir sus sensaciones, las circunstancias. Con el pretérito simple la narración continúa.

Era mi segunda noche en el mar. Noche de hambre y de sed y de desesperación. Me senti abandonado, después de que me aferré obstinadamente a la esperanza de los aviones. Solo esa noche, decidí que con lo único que contaba para salvarme era con mi voluntad $y$ con los restos de mis fuerzas.

Una cosa me asombraba: me sentia un poco débil pero no agotado. Llevaba casi cuarenta horas sin agua ni alimentos y más de dos noches y dos días sin dormir; pues había estado en vigilia toda la noche anterior al accidente. Sin embargo, yo me sentia capaz de remar. $(\mathrm{RN}, 45)$

Me sentí acompañado y alegre. No tenia hambre. Con más frecuencia que antes tomaba sorbos de agua de mar. Me sentía acompañado en medio de aquella cantidad de gaviotas que volaban en torno a mi cabeza. $(\mathrm{RN}, 76)$

En la Crónica de una muerte anunciada también hay ejemplos de cambio de plano. Con el pretérito simple el narrador presenta las acciones de una manera global, las acciones se suceden y el ritmo de la narración se acelera (CMA 94). Con el imperfecto se realza el segundo plano, la narración se detiene, se describen las circunstancias de los acontecimientos (CMA 94, CMA 124). Con el imperfecto se describen estados, las acciones en su curso, por lo que estos estados y acciones son simultáneas con otras acciones expresadas en pretérito simple y en pluscuamperfecto o imperfecto (CMA 94: entró/dejaba, estaban dando/fui; CMA 124: bordaba/sintiólllegaba, se asustólsabía).

Mi hermano Luis Enrique entró en la casa por la puerta de la cocina, que mi madre dejaba sin cerrojo para que mi padre no nos sintiera entrar. Fue al baño antes de acostarse, pero se durmió sentado en el retrete, y cuando mi hermano Jaime se levantó para ir a la 
escuela, lo encontró tirado boca abajo en las baldosas, y cantando dormido. Mi hermana la monja que no iria a esperar al obispo porque tenía una cruda de carretero, no consiguió despertarlo. "Estaban dando las cinco cuando fui al baño", me dijo. Más tarde, cuando mi hermana Margot entró a bañarse para ir al puerto, logró llevarlo a duras penas al dormitorio. Desde el otro lado del sueño, oyó sin despertar los primeros bramidos del buque del obispo. Después se durmió a fondo, rendido por la parranda, hasta que mi hermana la monja entró en el dormitorio tratando de ponerse el hábito a la carrera, y lo despertó con su grito de loca:

- Mataron a Santiago Nasar! (CMA, 94)

Un medio día de agosto, mientras bordaba con sus amigas, sintió que alguien llegaba a la puerta. No tuvo que mirar para saber quién era. "Estaba gordo y se le empezaba a caer el pelo, y ya necesitaba espejuelos para ver de cerca", me dijo. "Pero era él, carajo era él!" Se asustó porque sabía que él la estaba viendo tan disminuida como ella lo estaba viendo a él, y no creía que tuviera dentro tanto amor como ella para soportarlo. Tenía la camisa empapada de sudor, como lo habia visto la primera vez en la feria, y llevaba la misma correa y las mismas alforjas de cuero descosido con adornos de plata. (CMA, 124)

En El amor en los tiempos del cólera hay numerosos ejemplos de cambios de plano y de puesta de relieve. Los ejemplos citados presentan la simultaneidad de las acciones del segundo plano que están en imperfecto con las acciones en el primer plano expresadas en pretérito simple (ATC 77, ATC 149, ATC 169, ATC 189, ATC 309-310, ATC 427) y con otras acciones en el segundo plano expresadas con el imperfecto (ATC 118, ATC 122-123, ATC 184).

Don Pio Quinto Loayza murió cuando el hijo tenía diez años. (ATC, 77)

Poco después, ahogándose de calor junto a ella en el coche cerrado, no pudo soportar más la inclemencia de la realidad que se metia a borbotones por la ventanilla. (ATC, 149)

Su madre y sus hermanas estaban cenando café con leche y almojábanas en la mesa de ceremonias del comedor grande, cuando lo vieron aparecer en la puerta con el rostro transido y todo él deshonrado por el perfume de putas de los cuervos. (ATC, 169)

Después, mientras Hildebranda se bañaba escribió una carta a toda prisa, la dobló a toda prisa, la metió a toda prisa en el sobre, y antes de que Hildebranda saliera del baño se la mandó con Gala Placidia al doctor Juvenal Urbino. (ATC, 189)

Perdido entre la cándida muchedumbre que cantaba el Himno Nacional mientras el globo ganaba altura, Florentino Ariza se sintió de acuerdo con alguien a quien le oyó comentar en el tumulto que aquélla no era una aventura propia de una mujer, y menos de la edad de Fermina Daza. (ATC, 309-310) 
En el momento en que caía tuvo bastante lucidez para pensar que no iba a morir de aquel tropiezo porque no era posible en la lógica de la vida que dos hombres que habían amado tanto durante tantos años a la misma mujer, pudieran morir del mismo modo con sólo un año de diferencia. (ATC, 427)

Era la primera vez que montaba, pero el terror y las penurias incontables del viaje no le hubieran parecido tan amargas de no haber sido por la certidumbre de que nunca más vería a Florentino Ariza ni tendría el consuelo de sus cartas. (ATC, 118)

Sin embargo, el tiempo que él perdía en lamentos lo ganaba la hija en sus amores. Así, mientras él andaba castrando novillos y desbravando mulas en las tierras venturosas de sus cuñados, ella se paseaba con la rienda suelta en un tropel de primas comandadas por Hildebranda Sánchez, la más bella y servicial, cuya pasión sin porvenir por un hombre veinte años mayor, casado y con hijos, se conformaba con miradas furtivas. (ATC, 122-123)

Habia un tumulto frente al estudio del belga, porque estaban fotografiando a Beny Centeno, que por aquellos dias había ganado el campeonato de boxeo en Panamá. (ATC, 184)

El cambio de perspectiva, la presentación del segundo plano, la descripción del entorno y de las circunstancias de otras acciones (habia, saturaban, se percibía) y la presentación del primer plano, el desarrollo de la narración (empezaron a ladrar, hizo, saltaron, se escondieron, se hizo) se presentan en el ejemplo ATC 161-162, donde se crea un ambiente especial del rumor del agua en el fondo cortado repentinamente por el ladrar de los perros.

Habia un rumor invisible de agua continua, macetas de claveles en las cornisas y jaulas de pájaros raros en las arcadas. Los más raros, en una jaula muy grande, eran tres cuervos que al sacudir las alas saturaban el patio de un perfume equívoco. Varios perros encadenados en algún lugar de la casa empezaron a ladrar de pronto, enloquecidos por el olor del extraño. Pero un grito de mujer los hizo callar en seco, y numerosos gatos saltaron de todas partes y se escondieron entre las flores, asustados por la autoridad de la voz. Entonces se hizo un silencio tan diáfano, que a través del desorden de los pájaros y las sílabas del agua en la piedra se percibia el aliento desolado del mar. (ATC, 161-162)

En el ejemplo ATC 140-141 las acciones que se presentan globalmente, como sucesivas y perfectivas, están en el primer plano (en pretérito simple). Algunas acciones en el segundo plano son simultáneas con las acciones en pretérito simple del primer plano (prestó : ofrecían, trataba; compraba: pusieron) y califican las acciones del primer plano (hizo : tenian; encontró : aumentaba; dieron : tenía). En el segundo párrafo cambia la perspectiva de la narración, el narrador ya no expresa acciones que se suceden y que él ve desde fuera (perspectiva global), sino que observa las acciones desde otro punto de mira y las presenta cursivamente (jugaba, hacía, compraba, permitía, era, compraba). 
No prestó atención a los apremios de los culebreros que le ofrecían el jarabe para el amor eterno, ni a las súplicas de los mendigos tirados en los zaguanes con sus llagas humeantes, ni al indio falso que trataba de venderle un caimán amaestrado. Hizo un recorrido largo y minucioso, sin rumbo pensado, con demoras que no tenian otro motivo que el deleite sin prisa en el espiritu de las cosas. Entró en cada portal donde hubiera algo que vender, y en todas partes encontró algo que aumentaba sus ansias de vivir. Gozó con el hálito del vetiver de los paños en los arcones, se envolvió en sedas estampadas, $\underline{\text { se }}$ rió de su propia risa al verse disfrazada de manola con una peineta y un abanico de flores pintadas frente al espejo de cuerpo entero de El Alambre de Oro. En la bodega de ultramarinos destapó un barril de arenques en salmuera que le recordó las noches de nordeste, muy niña, en San Juan de la Ciénaga. Le dieron a probar una morcilla de Alicante que tenía un sabor de regaliz, y compró dos para el desayuno del sábado, y además unas pencas de bacalao y un frasco de grosellas en aguradiente. En la tienda de especias, por el puro placer del olfato, estrujó hojas de salvia y orégano en las palmas de las manos, y compró un puñado de clavos de olor, otro de anís estrellado, y otros dos de jengibre y de enebro, y salió bañada en lágrimas de risa de tanto estornudar por los vapores del pimiento de Cayena. En la botica francesa, mientras compraba jabones de Reuter y agua de benjuí, le pusieron detrás de la oreja un toque de perfume que estaba de moda en Paris, y le dieron una tableta de desodorante para después de fumar.

Jugaba a comprar, es cierto, pero lo que de veras le hacia falta lo compraba sin más vueltas, con una autoridad que no permitía pensar que lo hiciera por primera vez, pues era consciente de que no compraba sólo para ella sino también para él [...]. (ATC, 140-141)

\subsubsection{Repetición y enumeración}

Gabriel García Márquez entreteje en su obra lo real y lo ficticio. Su mundo ficticio es coherente con sus propias leyes interiores parecidas a las del mundo real. Con algunos recursos narrativos especiales como son la exageración, la enumeración, la repetición, el cambio de las cualidades de los objetos, etc. el autor mezcla los fenómenos mágicos y los hechos reales. Con la enumeración de acontecimientos normales y extraños se borra el límite entre ellos y se funde lo mágico con lo real. ${ }^{23}$ Los paradigmas verbales, sobre todo la oposición pretérito simple/imperfecto, desempeñan un papel primordial en el cambio del ritmo.

23 ... Gracias a las enumeraciones se apresa la máxima cantidad de tiempo en el mínimo espacio verbal, se narra el mayor número de hechos y se describe el mayor nümero de objetos con el menor número de palabras. La narración no necesita detenerse a dar precisiones, a matizar, a diferenciar: la enumeración la libera de esa necesidad porque, incorporadas a esa cascada sonora, cosas y acciones se desingularizan, se homologan, sus contenidos conceptuales pierden importancia, sus propiedades plásticas y fonéticas pasan a ser hegemónicas, y para que ellas (color, forma, música) sean perceptibles, la simple mención es suficiente. El uso continuo del procedimiento imprime por eso ciertos rasgos a la realidad ficticia: ligereza, plasticidad, y, en un sentido estricto, fugacidad. Todo en ella da la impresión de un espectáculo efimero, donde las imágenes desaparecen inmediatamente después de aparecer para dar paso a otras que a su vez desaparecen, como las figuras de un carrousel veloz o las imágenes de un film acelerado ... (Vargas Llosa, 1971, p. 594) 
La enumeración de acciones sucesivas o la repetición de acciones iguales en la perspectiva global acelera el ritmo de la narración y aumenta la tensión (CAS 11, CAS 167, CAS 174, CAS 257, CAS 297-298, ATC 131).

Lo envió a las autoridades acompañado de numerosos testimonios sobre sus experiencias $y$ de varios pliegos de dibujos explicativos, al cuidado de un mensajero que atravesó la sierra, se extravió en pantanos desmesurados, remontó ríos tormentosos y estuvo a punto de perecer bajo el azote de las fieras, la desesperación y la peste, antes de conseguir una ruta de enlace con las mulas del correo. (CAS, 11)

Con la temeridad atroz con que José Arcadio Buendía atraversó la sierra para fundar a Macondo, con el orgullo ciego con que el coronel Aureliano Buendía promovió las guerras inútiles, con la tenacidad insensata con que Úrsula aseguró la supervivencia de la estirpe, asi buscó Aureliano Segundo a Fernanda, sin un solo instante de desaliento. (CAS, 167)

Hicieron añicos media vajilla, destrozaron los rosales persiguiendo a un toro para mantearlo, mataron las gallinas a tiros, obligaron a bailar a Amaranta los valses tristes de Pietro Crespi, consiguieron que Remedios, la bella, se pusiera unos pantalones de hombre para subirse a la cucaña, y soltaron en el comedor un cerdo embadurnado de sebo. (CAS, 174)

Entonces Aureliano Segundo perdió el dominio. Se incorporó sin prisa, como si sólo pensara estirar los huesos, y con una furia perfectamente regulada y metódica fue agarrando uno tras otro los tiestos de begonias, las macetas de helechos, los potes de orégano, y uno tras otro los fue despedazando contra el suelo. Fernanda se asustó, pues en realidad no habia tenido hasta entonces una conciencia clara de la tremenda fuerza interior de la cantaleta, pero ya era tarde para cualquier tentativa de rectificación. Embriagado por el torrente incontenible del desahogo, Aureliano Segundo rompió el cristal de vidriera, y una por una, sin apresurarse, fue sacando las piezas de la vajilla y las hizo polvo contra el piso. Sistemático, sereno, con la misma parsimonia con que había empapelado la casa de billetes, fue rompiendo luego contra las paredes la cristalería de Bohemia, los floreros pintados a mano, los cuadros de las doncellas en barcas cargadas de rosas, los espejos de marcos dorados, y todo cuanto era rompible desde la sala hasta el granero, y terminó con la tinaja de la cocina que se reventó en el centro del patio con una explosión profunda. (CAS, 257)

Ni siquiera se permitió un día de descanso al cabo del largo viaje. Se puso un gastado overol de lienzo que habia llevado el esposo con otras prendas de motorista, y emprendió una nueva restauración de la casa. Desbandó las hormigas coloradas que ya se habian apoderado del corredor, resuscitó los rosales, arrancó la maleza de raiz, y volvió a sembrar helechos, oréganos y begonias en los tiestos del pasamanos. Se puso al frente de una 
cuadrilla de carpinteros, cerrajeros, albañiles que resanaron las grietas de los pisos, enquiciaron puertas y ventanas, renovaron los muebles y blanquearon las paredes por dentro y por fuera, de modo que tres meses después de su llegada se respiraba otra vez el aire de juventud y de fiesta que hubo en los tiempos de la pianola. (CAS, 297-298)

Lo que entonces contó era tan fascinante, que Florentino Ariza se prometió aprender a nadar, y a sumergirse hasta donde fuera posible, sólo por comprobarlo con sus ojos. Contó que en aquel sitio, a sólo dieciocho metros de profundidad, habia tantos veleros antiguos acostados entre los corales, que era imposible calcular siquiera la cantidad, y estaban diseminados en un espacio tan extenso que se perdían de vista. Contó que lo más sorprendente era que de las tantas carcachas de barcos que se encontraban a flote en la bahía, ninguna estaba en tan buen estado como las naves sumergidas. Contó que habia varias carabelas todavia con las velas intactas, y que las naves hundidas eran visibles en el fondo, pues parecia como si se hubieran hundido con su espacio y su tiempo, de modo que allí seguian alumbradas por el mismo sol de las once de la mañana del sábado 9 de junio en que se fueron a pique. Contó, ahogándose por el propio impetu de su imaginación, que el más fácil de distinguir era el galeón San José, cuyo nombre era visible en la popa con letras de oro, pero que al mismo tiempo era la nave más dañada por la artillería de los ingleses. Contó haber visto adentro un pulpo de más de tres siglos de viejo, cuyos tentáculos salian por los portillos de los cañones, pero habia crecido tanto en el comedor que para librarlo habría que desguazar la nave. Contó que había visto el cuerpo del comandante con su uniforme de guerra flotando de costado dentro del acuario del castillo, y que si no había descendido a las bodegas del tesoro fue porque el aire de los pulmones no le habia alcanzado. Ahi estaban las pruebas: un arete con una esmeralda, y una medalla de la Virgen con su cadena carcomida por el salitre. (ATC, 131)

Con la repetición de acciones iguales en el pretérito simple se crea la sensación de un rápido desplazamiento del tren y el pasar del paisaje (CAS 232). La perspectiva global expresada en pretérito simple acentúa con más fuerza la rápida sucesión de imágenes que observan Meme y el coronel Buendía. Cuando el desfile fantástico pasa, la ilusión se desvanece y queda solamente la soledad y la muerte (CAS 211).

Meme apenas se dio cuenta del viaje a través de la antigua región encantada. No vio las umbrosas e interminables plantaciones de banano a ambos lados de las líneas. No vio las casas blancas de los gringos, ni sus jardines aridecidos por el polvo y el calor, ni las mujeres con pantalones cortos y camisas de rayas azules que jugaban barajas en los pórticos. No vio las carretas de bueyes cargadas de racimos en los caminos polvorientos. No vio las doncellas que saltaban como sábalos en los ríos transparentes para dejarles a los pasajeros del tren la amargura de sus senos espléndidos, ni las barracas abigarradas y miserables de los trabajadores donde revoloteaban las mariposas amarillas de Mauricio Babilonia. (CAS, 232) 
En vez de ir al castaño, el coronel Aureliano Buendía fue también a la puerta de la calle y se mezcló con los curiosos que contemplaban el desfile. Vio una mujer vestida de oro en el cogote de un elefante. Vio un dromedario triste. Vio un oso vestido de holandesa que marcaba el compás de la música con un cucharón y una cacerola. Vio los payasos haciendo maromas en la cola del desfile, y le vio otra vez la cara a su soledad miserable cuando todo acabó de pasar, y no quedó sino el luminoso espacio en la calle y el aire lleno de hormigas voladoras, y unos cuantos curiosos asomados al precipicio de la incertidumbre. Entonces fue al castaño, pensando en el circo, pero ya no encontró el recuerdo. Metió la cabeza entre los hombros, como un pollito, y se quedó inmóvil con la frente apoyada en el tronco del castaño. La familia no se enteró hasta el día siguiente, a las once de la mañana, cuando Santa Sofía de la Piedad fue a tirar la basura en el traspatio y le llamó la atención que estuvieran bajando los gallinazos. (CAS, 211)

El ejemplo CAS 161 es el relato de un soldado (relato dentro del relato) inserto en la narración principal. Se repite el discurso indirecto, el verbo introductorio en imperfecto (decia) indica la habitud. El soldado iba regularmente a la ciudad, regresaba con monedas y noticias que contaba al coronel. El discurso indirecto del soldado que cuenta las noticias que había escuchado de otros, se introducce con un verbo en imperfecto y la conjunción que. Las noticias se narran con verbos en pretérito simple, y en pluscuamperfecto, si ya ocurrieron (habia firmado, habia venido, habian hecho, habia sido secuestrada, habia bailado) o en imperfecto, si están ocurriendo en el momento de la narración (estaba reformando).

Encerrado en su taller, la única relación con el resto del mundo era el comercio de pescaditos de oro. Uno de los antiguos soldados que vigilaron su casa en los primeros días de la paz, iba a venderlos a las poblaciones de la ciénaga, y regresaba cargado de monedas $y$ de noticias. Que el gobierno conservador, decia, con el apoyo de los liberales, estaba reformando el calendario para que cada presidente estuviera cien años en el poder. Que por fin se habia firmado el concordato con la Santa Sede, y que habia venido de Roma un cardenal con una corona de diamantes y en un trono de oro macizo, y que los ministros liberales se habian hecho retratar de rodillas en el acto de besarle el anillo. Que la corista principal de una compañia española, de paso por la capital, habia sido secuestrada en su camerino por un grupo de enmascarados, y el domingo siguiente había bailado desnuda en la casa de verano del presidente de la república. (CAS, 161)

Unas horas antes de morir Arcadio Buendía está pensando en su familia. (CAS 99-100). Sus reflexiones se indican con el verbo pensar en imperfecto. La repetición asidua crea la impresión de que el tiempo no pasa: por esa razón lo que él piensa está en imperfecto y las acciones que ocurren fuera de su mundo mental en pretérito simple. Primero se presenta un hecho en pretérito simple: Arcadio fue fusilado. Sigue un salto hacia atrás en el tiempo (dos horas antes de la muerte), cuando Arcadio tuvo que escuchar las interminables acusaciones y la descripción de lo que él pensó antes de morir. El escuchar de las acusaciones está pre- 
sentado como perfectivo (escuchó los interminables cargos de acusación), pero sus pensamientos están en perspectiva cursiva como si el narrador se hubiera acercado a su conciencia y describiera las acciones desde dentro. El tiempo cronológico se detuvo para Arcadio, perdió la noción del tiempo al sumergirse en sus pensamientos. Cuando el presidente del consejo de guerra inició su discurso final, Arcadio se dio cuenta del tiempo real y volvió a la realidad, al tiempo cronológico, para morir (las acciones están de nuevo en perspectiva global).

Al amanecer, después de un consejo de guerra sumario, Arcadio fue fusilado contra el muro del cementerio. En las dos últimas horas de su vida no logró entender por qué había desaparecido el miedo que lo atormentó desde la infancia. Impasible, sin preocuparse siquiera por demostrar su reciente valor, escuchó los interminables cargos de acusación. Pensaba en Úrsula, que a esa hora debia estar bajo el castaño tomando el café con José Arcadio Buendia. Pensaba en su hija de ocho meses, que aún no tenía nombre, y en el que iba a nacer en agosto. Pensaba en Santa Sofía de la Piedad, a quien la noche anterior dejó salando un venado para el almuerzo del sábado, y añoró su cabello chorreando sobre los hombros y sus pestañas que parecían artificiales. Pensaba en su gente sin sentimentalismos, en un severo ajuste de cuentas con la vida, empezando a comprender cuánto queria en realidad a las personas que más habia odiado. El presidente del consejo de guerra inició su discurso final, antes de que Arcadio cayera en la cuenta de que habian transcurrido dos horas. (CAS, $99-100$ )

La repetición de lo oía en imperfecto (ATC 42) acentúa la molesta e insistente costumbre del dr. Juvenal Urbino y la rutina en la que se transforma la vida conyugal después de muchos años de convivencia.

Lo oía despertar con los gallos, y su primera señal de vida era una tos sin son ni ton que parecía a propósito para que también ella despertara. Lo oía rezongar, sólo por inquietarla, mientras buscaba a tientas las pantuflas que debian de estar junto a la cama. Lo oía abrirse paso hasta el baño tantaleando en la oscuridad. Al cabo de una hora en el estudio, cuando ella se había dormido de nuevo, lo oía regresar a vestirse todavía sin encender la luz. [...] Ella lo oía a sabiendas de que ninguno de aquellos ruidos era indispensable, y que él los hacia a propósito fingiendo lo contrario, así como ella estaba despierta fingiendo no estarlo. (ATC, 42)

La repetición de la acción en imperfecto (repicaba) pone de relieve el repicar insistente y desesperado del teléfono (CAS 301).

Trató de reconstruir con la imaginación el arrasado esplandor de la antigua ciudad de la compañia bananera, cuya piscina seca estaba llena hasta los bordes de podridos zapatos de hombre y zapatillas de mujer, y en cuyas casas desbaratadas por la cizaña encontró el esqueleto de un perro alemán todavía atado a una argolla con una cadena de acero, y un teléfono que repicaba repicaba repicaba, hasta que él lo descolgó, entendió lo que una 
mujer angustiada y remota preguntaba en inglés, y le contestó que sí, que la huelga habia terminado, que los tres mil muertos habian sido echados al mar, que la compañia bananera se habia ido, y que Macondo estaba por fin en paz desde hacía muchos años. (CAS, 301)

\subsection{Las perifrasis verbales indicadoras de valores aspectuales}

Para los fines de este estudio las perífrasis verbales se definen de acuerdo con los criterios morfo-sintácticos y semánticos. La perífrasis verbal es una construcción compuesta, es la unión de dos elementos (verbos) que forman unidad funcional. El primer elemento es un verbo en forma personal y se le denomina el auxiliar. Es el que se conjuga, el que tiene significado gramatical y, por lo tanto, aporta información sobre la persona, el número, el tiempo y el aspecto. El segundo elemento, el auxiliado, llamado también verbo principal, es un verbo en forma no personal (infinitivo, gerundio, participio) y aporta esencialmente el valor semántico-léxico. ${ }^{24} \mathrm{Sin}$ embargo, hay que tener en cuenta que esta distribución de significados es arbitraria ya que el auxiliar en las perífrasis aporta también su valor semántico-léxico al conjunto ${ }^{25} \mathrm{y}$, asimismo, el auxiliado contribuye al valor general de la perífrasis verbal con su valor estrictamente gramatical. Las dos partes se vinculan mediante unión directa (sin nexos) o indirecta (con nexos: preposiciones, conjunciones, frases conjuntivas) en el caso de las perífrasis verbales con infinitivo. Todas las partes constitutivas de la perífrasis verbal crean una unidad semántica y sintáctica que tiene sus propios significado y función en el texto. La perífrasis verbal es un todo en el que los valores morfosintácticos y semánticos están estrechamente entretejidos: la perífrasis verbal no es simplemente la suma de los valores de sus elementos, estos no pueden separarse el uno del otro, no pueden aislarse ni sustituirse por otros elementos, ni pueden tener relaciones sintácticas propias (los dos verbos que constituyen la perifrasis verbal no son dos predicados separados sino que los dos verbos juntos forman un predicado. ${ }^{26}$ Los valores aspectuales (y también modales y temporales) de las perífrasis verbales dependen también de los paradigmas verbales en que se encuentran, de los complementos de tiempo, modo, etc. y de otros elementos del texto en que figuran. El señalamiento de los valores aspectuales de las perífrasis verbales es, por lo tanto, consecuencia de influencias recíprocas y complejas entre sus partes constitutivas insertas en el entorno textual.

24 La única excepción son las perifrasis copulativas, construcciones perifrásticas formadas de dos verbos conjugados relacionados con la conjunción y. Son primordialmente aspectuales y, según Coseriu (1977, p. 79-151), indican acciones en su totalidad englobando el inicio y el término. La acción se presenta como no dividida, intensa, brusca, rápida con matices de sorpresa, de algo inesperado y repentino.

25 Muchos verbos auxiliares mantienen parcial o totalmente su valor léxico en las perifrasis verbales como por ejemplo empezar a + infinitivo, terminar de + infinitivo, etc.

26 Ya que las perífrasis verbales actúan como un todo es muy raro que entre ellas se intercalen otras palabras. Pero esto puede ocurrir debido principalmente a efectos estilisticos y/o ritmicos:

Sé que hay mujeres asomadas a las ventanas, ansiosas de espectáculo, y que permanecen alli, asomadas, sin acordarse de que en los fogones está la leche hirviendo y el arroz seco. $(\mathrm{LH}, 84)$

"Estuvo como media hora cambiándose la gasa con que llevaba envuelta la pinga", me dijo Pablo Vicario. (CMA, 82) 
Tradicionalmente, para facilitar su estudio, las perifrasis verbales se dividen de acuerdo con la forma en perífrasis verbales con infinitivo, gerundio y participio o de acuerdo con sus valores en perífrasis modales, aspectuales y temporales aunque en este último caso es difícil hacer una división tajante entre los tres valores que indican las perífrasis porque generalmente los valores se combinan y dependen del entorno textual en el que se encuentran. En este estudio nos limitamos a aquellas perífrasis verbales que indican, en conjunción a otros elementos del texto, primordialmente valores aspectuales. A continuación se analizan las perífrasis verbales aspectuales más frecuentes (perífrasis verbales con infinitivo y con gerundio) en las obras estudiadas.

\subsubsection{Perífrasis verbales aspectuales con infinitivo}

\subsubsection{Perifrasis verbales con infinitivo que indican las fases de la acción}

Las perífrasis verbales incoativas indican, por una parte, la fase de la acción que está por realizarse - la fase inminente de la acción, y, por otra parte, la fase inicial de la acción.

En los textos estudiados la fase inminente de la acción se indica con la forma estar a punto de + infinitivo (ATC 43, ATC 268):

Pero fue por uno de esos juegos triviales que los primeros treinta años de vida en común estuvieron a punto de acabarse porque un día cualquiera no hubo jabón en el baño. (ATC, 43)

Estaba a punto de llorar por la derrota, pero Florentino Ariza le cambió el ánimo con su instinto de cazador nocturno. (ATC, 268)

La inminencia de la acción puede señalarse también con la perífrasis verbal ir $a+$ infinitivo. Con esta perífrasis se indica una acción a punto de realizarse pero no se realiza (ATC 218) o una acción cuya realización es inminente e inevitable (ATC 269):

Iba a encenderla, pero ella le detuvo el brazo, diciendo: "Yo veo mejor con las manos". (ATC, 218)

Cuando se dio cuenta de que habia empezado a amarla, ella estaba ya en la plenitud de los cuarenta, y él iba a cumplir treinta. (ATC, 269)

El coronel Aureliano Buendia estaba aquella noche terminando el poema del hombre que se había extraviado en la lluvia cuando la muchacha entró al cuarto. (CAS, 105)

Llevaba mucho tiempo pensando en él sin ninguna ilusión cuando tuvo que acompañar a su madre a un examen de la vista en el hospital de Riohacha. (CMA, 120)

Generalmente la inclusión de otra palabra entre dos elementos de una construcción verbal del tipo de perífrasis verbal es señal de que la construcción en cuestión no es perifrástica. En el ejemplo ATC 189 la intercalación del complemento las noches en claro entre las dos formas verbales indica que la estructura no es perifrástica. El verbo pasar mantiene sus propios valores semántico-sintácticos y el gerundio llorando tiene función adverbial de complemento de modo.

Tránsito Ariza hizo más que lo posible por consolarlo con recursos de novia cuando se dio cuenta de que habia perdido el habla y el apetito y se pasaba las noches en claro llorando sin sosiego, y al cabo de una semana consiguió que comiera otra vez. (ATC, 189) 
La fase inicial de la acción en los textos analizados se indica con las siguientes perífrasis incoativas en perspectiva global y en perspectiva cursiva:

Empezar (comenzar) a + infinitivo (LH 16, LH 26, LH 38)

Cuando descubro que hay moscas en la habitación comienza a torturarme la idea de que el ataúd ha quedado lleno de moscas. $(\mathrm{LH}, 16)$

$Y$ mientras lo hacia, se tenía la impresión de que durante los años anteriores se habia mantenido parada en una sola edad estática y sin tiempo y que aquella noche, al recordar, ponía otra vez en movimiento su tiempo personal y empezaba a padecer su largamente postergado proceso de envejecimiento. $(\mathrm{LH}, 26)$

Fue él quien empezó a moverse detrás de los espinos. (LH, 38)

Ponerse $a+$ infinitivo, menos neutral que las dos anteriores, le añade al inicio de la acción un matiz subjetivo: la voluntad del sujeto para realizar la acción (CAS 322, ATC 39): Después de cortarle el ombligo, la comadrona se puso a quitarle con un trapo el ungüento azul que cubria el cuerpo, alumbrada por Aureliano con una lámpara. (CAS, 322)

Pero un día se puso a hacer gracias de acróbata en los travesaños de la cocina y se cayó en la olla del sancocho en medio de su propia algarabia naval del sálvese quien pueda. y con tan buena fortuna que la cocinera alcanzó a sacarlo con el cucharón, escaldado y sin plumas, pero todavia vivo. (ATC, 39)

Las perifrasis verbales incoativas echar(se) $a+$ infinitivo, romper $a+$ infinitivo, soltarse $a+$ infinitivo, darse $a+$ infinitivo conllevan matices expresivos y estilísticos, al inicio de la acción se le añaden significados de brusquedad, sorpresa, inicio repentino (LH 74, CAS 126, CMA 34, ATC 149, CAS 250):

$Y$ él se vuelve hacia mí y echa a correr diciendo: "Bueno, entonces vamos". (LH, 74)

El capitán intentó catearlo por la fuerza, y Aureliano José, que andaba desarmado, se echó a correr (CAS, 126)

Mis hermanos menores empezaron a salir de los otros cuartos. Los más pequeños, tocados por el soplo de la tragedia, rompieron a llorar. (CMA, 34)

Derrotado, volvió la cabeza para que no lo viera su madre, y se soltó a llorar en silencio. (ATC, 149) 
Como no sabia inglés, y como apenas podía distinguir las ciudades más conocidas y las personalidades más corrientes, se dio a inventar nombres y leyendas para satisfacer la curiosidad insaciable de los niños. (CAS, 250)

Con la perifrasis verbal empezar (comenzar) por + infinitivo se señala el inicio de un proceso de toda una serie de acciones implícitas y explícitas. Las acciones en la mayoría de los casos no se mencionan pero se deducen del contexto o de elementos extralingüísticos. Tienen el mismo valor que las perifrasis verbales empezar (comenzar) + gerundio. Normalmente se encuentran en el mismo contexto que las perífrasis verbales continuar por + infinitivo (o continuar + gerundio), acabar (terminar) por + infinitivo o acabar (terminar) + gerundio (ATC 82, CAS 129).

Empezó por convencerlo de que no entregara el mamotreto lírico, con el que sólo lograría asustar a la niña de sus sueños, a quien suponia tan verde como él en los negocios del corazón. (ATC, 82)

Empezó por aconsejarle que moderara el rigor de su luto, que ventilara la casa, que le perdonara al mundo la muerte de José Arcadio. (CAS, 129)

Con las perifrasis verbales terminativas se indica la fase final de la acción. Se puede acentuar el término de la acción (acabar de + infinitivo, terminar de + infinitivo), la interrupción de la acción (dejar de + infinitivo) o la culminación de una serie de acciones anteriores (terminar por + infinitivo, acabar por + infinitivo, llegar $a+$ infinitivo, venir $a+$ infinitivo, alcanzar a + infinitivo).

Las perifrasis verbales acabar de + infinitivo, terminar de + infinitivo son equivalentes cuando los dos verbos auxiliares mantienen su significado básico. Terminar de + infinitivo (RN 84, ATC 174) se usa en todos los paradigmas verbales para indicar la fase final de la acción, con acabar de + infinitivo se expresa la fase final cuando el auxiliar no está en presente o en imperfecto ( $\mathrm{RN}$ 107), aunque son posibles también estos casos (en el ejemplo ATC 181 se señala la habitud).

Cuando terminé de comer, no me sentí más aliviado. $(\mathrm{RN}, 84)$

Apareció acompañada por una novicia a las nueve de la mañana, y ambas tuvieron que entretenerse media hora con las jaulas de pájaros mientras Fermina Daza terminaba de bañarse. (ATC, 174)

Cuando acabé de dibujar, examinó los papeles, dijo algunas palabras confusas y comenzó a hacerme preguntas sobre mi aventura. $(\mathrm{RN}, 107)$

Cuando acababa de lavar las jaulas y poner la comida a los pájaros, y de cuidar que nada les hiciera falta a las flores, se quedaba sin rumbo. (ATC, 181) 
Con el auxiliar en presente o imperfecto se indica una acción perfectiva ocurrida en un pretérito reciente referente al momento del habla o al punto de referencia indicado, es decir, que acabar de + infinitivo expresa tanto valores aspectuales (término de la acción) como temporales (tiempo reciente). (ATC 421)

- Ya da lo mismo - dijo- acabo de cumplir setenta y dos años. (ATC, 421)

Con dejar de + infinitivo se señala la interrupción de una acción (ATC 272, RN 28). Si la perífrasis verbal está en forma negativa, ya no se usa para expresar valor terminativo sino para indicar la duración (LH 57) o la repetición (CMA 24-25) de una acción. No parar de + inf., que en el texto estudiado no es frecuente (CMA 116), es sinónimo de no dejar de + inf:

Era tal su arrebato declamatorio que a veces seguia recitando a gritos mientras hacia el amor, y Florentino Ariza tenía que ponerle el chupón en la boca a viva fuerza, como se hacia con los niños para que dejaran de llorar. (ATC, 272)

Por un instante dejé de ver la balsa, pero procuré no perder la dirección. (RN, 28)

Mi madrastra hablaba sin dejar de coser, sin levantar la vista del tambor sobre el cual estaba grabando símbolos, bordando laberintos blancos. $(\mathrm{LH}, 57)$

Aunque no habian dejado de beber desde la víspera de la parranda, ya no estaban borrachos al cabo de tres días, sino que parecian sonámbulos desvelados. (CMA, 24-25)

En la ventana de una casa frente al mar, bordando a máquina en la hora de más calor, habia una mujer de medio luto con antiparras de alambre y canas amarillas, y sobre su cabeza estaba colgada una jaula con un canario que no paraba de cantar. (CMA, 116)

La conclusión o la culminación de un proceso anterior de una serie explícita o implícita de acciones se señala con las perífrasis verbales terminar por + infinitivo (CMA 54), acabar por + infinitivo (ATC 119), llegar a + infinitivo (CAS 15), venir $a+$ infinitivo (ATC 358), alcanzar $a+$ infinitivo (CMA 152):

Sin embargo, aun sin la bendición del obispo, la fiesta adquirió una fuerza propia tan dificil de amaestrar, que al mismo Bayardo San Román se le salió de las manos y terminó por ser un acontecimiento público. (CMA, 54)

Aquellas penurias eran familiares a Lorenzo Daza, que había traficado por la región durante media vida, y casi siempre se encontraba con amigos viejos al amanecer. Para la hija era una agonía perpetua. La hedentina de las cargas de bagre salado, sumada a la inapetencia propia de la añoranza, acabaron por estropearle el hábito de comer, y si no enloqueció de desesperación fue porque siempre encontró un alivio en el recuerdo de Florentino Ariza. (ATC, 119) 
El concierto de tantos pájaros distintos llegó a ser tan aturdidor, que Úrsula se tapó los oidos con cera de abejas para no perder el sentido de la realidad. (CAS, 15)

Recurrió por último a cuantas yerbas de indios pregonaban en el mercado público, y a cuantos específicos mágicos y pócimas orientales se vendian en el Portal de los Escribanos, pero cuando vino a darse cuenta de la estafa ya tenía una tonsura de santo. (ATC, 358)

Santiago Nasar necesitaba apenas unos segundos para entrar cuando cerró la puerta. Alcanzó a golpear varias veces con los puños, y en seguida se volvió para enfrentarse a manos limpias con sus enemigos. (CMA, 152)

\subsubsection{Perífrasis verbales con infinitivo que indican la repetición}

Volver $a+$ infinitivo expresa en la mayoría de los casos una sola repetición de la acción (perífrasis verbal iterativa) especialmente si el verbo conjugado se encuentra en pretérito simple o en otro paradigma verbal que sirve para expresar la perspectiva global (ATC 345). Para acentuar la iteración se pueden usar dos recursos iterativos (la perífrasis verbal en cuestión y el verbo con el prefijo re-) y lograr con esta redundancia efectos especiales (ATC 441).

Entonces Fermina Daza volvió a ver su pueblo grande en el marasmo de las dos de la tarde. Volvió a ver las calles que más bien parecian playones con charcos cubiertos de verdín, y volvió a ver las mansiones de los portugueses con sus escudos heráldicos tallados en el pórtico y celosias de bronce en las ventanas [...]. (ATC, 345)

Volvió a reiterarle la invitación más adelante, cuando se decidió a seguir viva sin el esposo, y entonces le pareció más probable. (ATC, 441)

En lugar de volver $a+$ infinitivo se puede usar también el sinónimo menos frecuente tornar a + infinitivo (LH 66):

- Yo no, coronel-dijo. Y sonrió pero tornó a ponerse serio de inmediato. - Mis hijos no serian como los suyos. $(\mathrm{LH}, 66)$

Cuando el auxiliar volver se encuentra en imperfecto se indica una repetición regular o una costumbre, si otros elementos del contexto lo permiten (complementos circunstanciales, perífrasis verbales progresivas, acciones repetitivas, etc.) (CAS 17):

No podian regresar, porque la trocha que iban abriendo a su paso se volvía a cerrar en poco tiempo, con una vegetación nueva que casi veían crecer ante sus ojos. (CAS, 17)

Con soler + infinitivo se indican acciones habituales (ATC 138, CAS 21):

[...] Volvió a ver la llovizna triste del parquecito, la estatua del héroe decapitado, el escaño de mármol donde Florentino Ariza solía sentarse con el libro de versos. (ATC, 138) 
Por último, llegó hasta el lugar donde Melquiades solía plantar su tienda, y encontró un armenio taciturno que anunciaba en castellano un jarabe para hacerse invisible. (CAS, 21)

3.2.1.3 Las perifrasis verbales nefastas de Gabriel García Márquez: haber de + infinitivo e ir a +infinitivo

La perifrasis verbal haber de + inf. es una de las perífrasis preferidas de Gabriel García Márquez. Con el auxiliar en imperfecto el narrador omnisciente expresa el futuro del pasado con un matiz de fatalidad y anuncia eventos que se desarrollarán más tarde en la vida de los protagonistas. La perífrasis introduce Cien años de soledad y se repite a lo largo de la novela. Su valor predominante es el valor modal de obligación que en conjunción con los valores temporal de posterioridad y aspectual de inminencia de la acción resulta en un matiz de algo fatal, ineludible, trágico. Se repite como una fórmula mágica, anunciadora de eventos trágicos que marcan la vida de los protagonistas. La primera frase de la novela es importante para la comprensión de toda la obra. Con ella se traslada la acción hacia adelante, a un momento fatal, y de allí la acción se vuelve hacia atrás para seguir el curso de la historia de Macondo (CAS 9).

Muchos años después, frente al pelotón de fusilamiento, el coronel Aureliano Buendia había de recordar aquella tarde remota en que su padre lo llevó a conocer el hielo. (CAS, 9)

Con la perífrasis se indican momentos fatales en la vida de los protagonistas no solamente en Cien años de soledad sino también en los demás textos analizados (CAS 231, LH 52, CMA 58, ATC 37).

Los acontecimientos que habian de darle el golpe mortal a Macondo empezaban a vislumbrarse cuando llevaron a la casa al hijo de Meme Buendía. (CAS, 231)

Habian de transcurrir estos nueve años sin que se volviera a saber nada de él, sin que su padre, que lo ayudó a adelantar los preparativos de ese viaje sin término, haya vuelto a decir una palabra en relación con su regreso. (LH, 52)

Esa precisión habia de perseguirme durante muchos años pues Santiago Nasar me habia dicho a menudo que el olor de las flores encerradas tenía para él una relación inmediata con la muerte, y aquel día me lo repitió al entrar al templo. "No quiero flores en mi entierro", me dijo, sin pensar que yo habia de ocuparme al dia siguiente de que no las hubiera. (CMA, 58)

En esta casa no entrará nada que no hable - dijo.

Lo dijo para poner término a las argucias de su mujer, empecinada otra vez en comprar un perro, y sin imaginar siquiera que aquella generalización apresurada habia de costarle la vida. $(\mathrm{ATC}, 37)$ 
Con la perífrasis se señalan también acontecimientos fatídicos que marcaron profundamente a los protagonistas. Nunca los olvidarán y seguirán obsesionados con ellos durante toda su vida (CAS 13, CAS 239, ATC 290):

Los niños se asombraron con sus relatos fantásticos. Aureliano que no tenia entonces más de cinco años, habia de recordarlo por el resto de su vida como lo vio aquella tarde, sentado contra la claridad metálica y reverberante de la ventana, alumbrando con su profunda voz de órgano los territorios más oscuros de la imaginación, mientras chorreaba por sus sienes la grasa derretida por el calor. José Arcadio, su hermano mayor, habia de transmitir aquella imagen maravillosa, como un recuerdo hereditario a toda su descendencia. (CAS, 13)

Muchos años después, ese niño había de seguir contando, sin que nadie se lo creyera, que había visto al teniente leyendo con una bocina de gramófono el Decreto Número 4 del Jefe Civil y Militar de la provincia. (CAS, 239)

A Paris, a pesar de su lluvia perpetua, de sus tenderos sórdidos y la groseria homérica de sus cocheros, habia de recordarla siempre como la ciudad más hermosa del mundo, no porque en realidad lo fuera, sino porque se quedó vinculada a la nostalgia de sus años más felices. (ATC, 290)

La perífrasis verbal ir a +infinitivo es la perífrasis más manifiesta de Crónica de una muerte anunciada. Sus valores temporales (posterioridad), aspectuales (inminencia de la acción) y modales (intención) se funden para concederle un matiz de anticipación y previsión cuando el verbo auxiliar está en imperfecto. El narrador omnisciente anticipa la acción, pero deja al lector en suspense ya que con la perífrasis no se expresa explícitamente si la acción llegará a su final o no. En la primera frase de Crónica de una muerte anunciada con la perífrasis verbal iban a matar no se expresa una acción perfectiva, una perspectiva global, sino que se acentúa la inminencia de la acción y el valor modal de intención. Después de la primera frase quedan abiertas las dos posibilidades. Al lector se le informa sobre el resultado trágico solamente unas líneas más abajo.

El día en que lo iban a matar. Santiago Nasar se levantó a las 5:30 de la mañana para esperar el buque en que llegaba el obispo. (CMA, 9)

Ir a + infinitivo se repite a lo largo de toda la novela como un refrán y con ella se anticipan acciones que realmente se realizan (CMA 15, CMA 24) y otras, como en los ejemplos CMA 64 y CMA 146, que no se realizan.

El día en que lo iban a matar, su madre creyó que él se había equivocado de fecha cuando lo vio vestido de blanco. (CMA, 15)

Los hombres que lo iban a matar, se habian dormido en los asientos... (CMA, 24) 
"Lo único que recuerdo es que me sostenía por el pelo con una mano y me golpeaba con la otra con tanta rabia que pensé que me iba a matar", me contó Angela Vicario. (CMA, 64)

Sin embargo, le pareció inconcebible que a Santiago Nasar lo fueran a matar y en cambio se le ocurrió que lo iban a casar a la fuerza con Ángela Vicario para que le devolviera la honra. (CMA, 146)

\subsubsection{Perífrasis verbales aspectuales con gerundio}

Las perífrasis verbales con gerundio, el cual indica acciones progresivas y durativas, se usan generalmente para indicar acciones en su progresión, su desarrollar y su duración.

\subsubsection{Perifrasis verbales durativas y progresivas}

La perífrasis verbal de uso más frecuente es estar + gerundio que se puede emplear en todos los paradigmas verbales, en perspectiva cursiva y global. En el corpus prevalecen el presente, el imperfecto y el pretérito simple. Con esta perífrasis se acentúa el transcurrir y la duración de la acción que temporalmente no engloba únicamente el momento del habla u otro punto de referencia sino que se refiere a un lapso de tiempo mucho más amplio. Matte Bon (1992, II, p. 160) mantiene que con esta perífrasis verbal el hablante no quiere presentar la realidad extralingüistica objetiva y detalladamente sino que quiere comentarla, explicarla y que el momento emotivo cobra importancia. (ATC 44).

Al cabo de un largo rumor de almidones de linos en la oscuridad, el doctor Urbino habló consigo mismo:

- Hace como una semana que me estoy bañando sin jabón - dijo. (ATC 44)

Con estar + gerundio el hablante actualiza la acción en la esfera del presente (CMA 137) o del pasado (CMA 94). Con esta perífrasis verbal el hablante expresa estados, procesos, acciones progresivas, durativas y repetitivas, pero no puede expresar acciones puntuales. ${ }^{27}$ Puede presentar la acción en perspectiva cursiva (se acentúa el progresar de la acción - LH 59) o en perspectiva global (la acción es progresiva, durativa o repetitiva pero terminada LH 32):

- Estos pobres muchachos no matan a nadie - dijo.

- Están bebiendo desde el sábado - dijo Cristo Bedoya. (CMA, 137)

"Estaban dando las cinco cuando fui al baño", me dijo. (CMA, 94)

${ }^{27}$ El ejemplo * Juan está dando un grito es agramatical debido a que la perifrasis verbal se usa para indicar valores progresivos, durativos, repetitivos. La frase se vuelve gramatical si se le añade algún indicador de repetición o duración: el uso del presente simple (Juan da un grito) o del plural (Juan está dando gritos). 
Antes de que yo pudiera preguntar qué estaba pasando, por qué estaban sucediendo cosas extrañas en mi propia casa sin que yo lo supiera, tu padre había venido a decirme: "No tienes nada que preguntarle a Meme". [...] $(\mathrm{LH}, 59)$

La banda rural estuvo tocando piezas sentimentales hasta cuando vino un muchacho, jadeante, reventando a decir que la mula del párroco estaba en la última vuelta del camino. (LH, 32)

Andar + gerundio también se usa para señalar acciones durativas y progresivas pero, gracias al auxiliar andar, la perífrasis es más expresiva y dinámica. A la idea de progresión se une un matiz subjetivo burlón e irónico (ATC 124, CAS 199).

Por aquellos días, Hildebranda Sánchez andaba delirando de ilusiones después de visitar a una pitonisa cuya clarividencia la habia asombrado. (ATC, 124)

No bien Remedios, la bella, habia subido al cielo en cuerpo y alma, y ya la desconsiderada Fernanda andaba refunfuñando en los rincones porque se habia llevado las sábanas. (CAS, 199)

Con ir(se) + gerundio el hablante acentúa el transcurrir progresivo y la duración de la acción. El lento desarrollar de la acción se refuerza con complementos circunstanciales de tiempo o modo. Tiene un fuerte valor expresivo y se usa a menudo para describir, acentuar el lento progresar de las acciones, inmovilizar las acciones en el tiempo. Se usa tanto en la perspectiva cursiva (el lento progresar y la duración se acentúan - CAS 314, ATC 61) como en la perspectiva global (el progresar y el durar de la acción se presentan como terminados-CAS 62-63, ATC 60).

Pero poco a poco lo fue abandonando a su soledad, porque cada vez se les hacía más dificil la comunicación. Estaba perdiendo la vista y el oído, parecía confundir a los interlocutores con personas que conoció en épocas remotas de la humanidad, y contestaba a las preguntas con un intrincado batiburrillo de idiomas. (CAS, 62-63)

Sin embargo, y aunque él mismo no parecía advertirlo, aquellas cartas de recuperación y estímulo se iban transformando poco a poco en pastorales de desengaño. (CAS, 314)

Poco a poco, mientras yacía con los ojos cerrados después de la siesta diaria, había ido sintiéndolas dentro, una a una, sintiendo hasta la forma de su corazón insomne, su higado misterioso, su páncreas hermético, y había ido descubriendo que hasta las personas más viejas eran menores que él [...]. (ATC, 60)

Pero lo que más le inquietaba era la desconfianza que tenía en su propia razón: poco a poco, en un naufragio ineluctable, sentia que iba perdiendo el sentido de la justicia. (ATC, 61) 
Llevar + gerundio sirve para indicar acciones durativas limitadas en un marco temporal. La acción se desarrolla desde un momento determinado hasta el momento del habla o punto de referencia. Esta delimitación en el tiempo hace incompatible su uso en perspectiva global (ATC 263, CMA 120).

Por primera vez en los veintisiete años interminables que llevaba esperando, Florentino Ariza no pudo resistir la punzada de dolor de que aquel hombre admirable tuviera que morirse para que él fuera feliz. (ATC, 263)

Llevaba mucho tiempo pensando en él sin ninguna ilusión cuando tuvo que acompañar a su madre a un examen de la vista en el hospital de Riohacha. (CMA, 120)

\subsubsection{Perífrasis verbales con gerundio que sirven para indicar las fases de la acción}

Empezar (comenzar) + gerundio y terminar (acabar) + gerundio equivalen a las perífrasis verbales empezar (comenzar) por + infinitivo y terminar (acabar) por + infinitivo y sirven para indicar respectivamente la fase inicial (ATC 277) y la fase final (ATC 287, CAS 90) de un proceso.

Empezaban viviendo como parásitas de sombras en los caserones desiertos, se volvian confidentes de sus sirvientas, amantes de sus almohadas, sin nada que hacer después de tantos años de cautiverio estéril [...] Seguian poniendo su jabón en el baño, la funda con sus iniciales en la cama, el plato y los cubiertos en su lugar de la mesa, por si acaso volvian de la muerte sin avisar, como solian hacerlo en vida. Pero en aquellas misas de soledad iban tomando conciencia de que otra vez eran dueñas de su albedrío [...] (ATC, 277)

Ella empezaba a hacerlo con las migajas de amor que todavia le sobraban de Europa, y ambos se iban dejando traicionar por los recuerdos, ablandándose sin quererlo, queriéndose sin decirlo, y terminaban muriéndose de amor por el suelo, embadurnados de espumas fragantes, mientras oían a las criadas hablando de ellos en el lavadero: "Si no tienen más hijos es porque no tiran." (ATC, 287)

Llegó a ser tan sincera en el engaño que ella misma acabó consolándose con sus propias mentiras. (CAS, 90)

Salir + gerundio expresa un valor parecido a terminar (acabar) + gerundio, es decir, el final, a menudo no esperado, de un proceso (ATC 426).

Si hubiera contado con el consentimiento de Fermina Daza, ninguna ocasión hubiera sido más propicia. Más aún: después de lo que habian hablado en aquel almuerzo histórico, el formalismo de la solicitud salía sobrando. (ATC, 426) 
La fase media (la fase de la duración) del proceso se indica con las perífrasis verbales seguir (continuar) + gerundio. Se emplean en todos los paradigmas verbales tanto en perspectiva cursiva como en perspectiva global. Las dos perífrasis presuponen un proceso o estado anterior que continúa orientado hacia adelante ( $R N 37, \mathrm{RN} 38, \mathrm{RN} 97$ ).

Volvi a ponérmelo en la muñeca y seguí mirándolo minuto a minuto, como esa tarde había estado mirando el horizonte en espera de los aviones; hasta cuando me dolieron los ojos. (RN, 37)

La balsa seguía avanzando no podia calcular cuánto habia avanzado durante la noche, pero todo seguia siendo igual en el horizonte, como si no me hubiera movido un centímetro. (RN, 38)

El no contestó en seguida. Continuó examinándome enigmáticamente, sin parpadear, con la carabina apoyada en el suelo. (RN, 97)

\section{Conclusiones}

$\mathrm{El}$ análisis de algunas formas verbales (paradigmas verbales y perífrasis verbales) que sirven para señalar valores aspectuales en cinco obras narrativas de Gabriel García Márquez demuestra que las formas verbales analizadas son unos potentes recursos lingüísticos para la expresión de la temporalidad y la aspectualidad y tienen un fuerte valor expresivo, se usan para lograr efectos estilísticos especiales. El análisis de las perspectivas del narrador, de las oposiciones aspectuales de ciertos paradigmas verbales, de los valores aspectuales de algunas perífrasis verbales que parecen especializarse para indicar la aspectualidad comprueban que el aspecto verbal, a pesar de que aún hoy día siga teniendo oponentes que consideran el aspecto como una especialidad eslava inexistente en español, no sólo está presente en español sino que tiene un papel muy vital e importante, nada inferior al de la temporalidad. En el complejo mundo del texto un sinfín de elementos dependientes entre sí sirven para expresar los más variados matices de temporalidad, aspectualidad, modalidad. El hablante, narrador en nuestro caso, tienen a su disposición recursos muy variados para expresar los matices más rebuscados. Esta riqueza y disponibilidad en la lengua española se refleja a perfección en las obras narrativas de Gabriel García Márquez.

\section{BIBLIOGRAFÍA}

Alarcos Llorach, E. (1972), Estudios de gramática funcional del español. Madrid: Gredos. 51-108.

Alarcos Llorach, E. (1975), Otra vez sobre el sistema verbal español. Homenaje a la memoria de D. Antonio Rodríguez-Moñino 1910-1970. Madrid: Castalia. 9-26. BAL, M. (1987), Teoría de la narrativa. Madrid: Cátedra.

Beaugrande, R. de, Dressler, U. (1992), Uvod v besediloslovje. Ljubljana: Park. 
Bello, A. (1847/1988), Gramática de la lengua castellana destinada al uso de los americanos, I, II con las notas de Rufino José Cuervo. Estudio y edición de Ramón Trujillo. Madrid: Arco Libros.

Berschin, H. (1975), A propósito de la teoría de los tiempos verbales. Perfecto simple y perfecto compuesto en el español peninsular y colombiano. Thesaurus, BICC XXX/3, Bogotá: ICC. 539-556.

BinNick, R. I. (1991), Time and the Verb. A Guide to Tense and Aspect. New York-Oxford: Oxford University Press.

BosQue, I. (1990), Tiempo y aspecto en español. Madrid: Cátedra.

Bull, W. E. (1968), Time, Tense and the Verb (A Study in Theoretical and Applied Linguistics with Particular Attention to Spanish). Berkeley and Los Angeles: University of California Press.

Comrie, B. (1976), Aspect. Cambridge: Cambridge University Press.

COMrIE, B. (1990), The Typology of Tense-Aspect Systems in European Languages. Lingua e Stile, anno XXV/2. 259-272.

COSERIU, E. (1960), Sobre las llamadas "construcciones con verbos de movimiento": un problema hispánico. Comunicação apresentada ao IV Colóquio Internacional de Estudos Luso-Brasileiros, Salvador (Bahia), 1959. Montevideo.

COSERIU, E. (1977), Estudios de linguüistica románica. Madrid: Gredos.

COSERIU, E. (1980), Aspect verbal ou aspects verbaux? Quelques questions de théorie et de méthode. La notion d'aspect, Colloque organisé par le Centre d' Analyse Syntaxique de I'Université de Metz, Paris: Klincksieck.

DieTRICH, W. (1983), El aspecto verbal perifrástico en las lenguas románicas. Madrid: Gredos.

FleisChMAN, S. (1990), Tense and Narrativity. London: Routledge.

FeRnÁnedez dE CASTRO, F. (1990), Las perifrasis verbales en español. Comportamientos sintácticos e historia de su caracterización. Oviedo: Series Minor.

FERNÁNDEZ RAMíREZ, S. (1986), Gramática española, 4. El verbo y la oración. Madrid: Arco/ Libros.

GILI GAYA, S. (1976), Curso superior de sintáxis española. Barcelona: Bibliograf.

Gómez TORrego, L. (1988), Perífrasis verbales. Sintaxis, semántica y estilística. Madrid: Arco/Libros.

GonZÁles Boixo, J. C. (1983), Claves narrativas de Juan Rulfo. León: Editorial Universidad de León.

HARRIS, M. (1982), The "Past Simple" and the "Present Perfect" in Romance. Studies in the Romance Verb edited by N. Vincent and M. Harris. London-Canberra: Croom Helm. 42-70.

HeRnÁNDEZ Alonso, C. (1986), Gramática funcional del español. Madrid: Gredos.

LOPE Blanch, J. (1961), Sobre el uso del pretérito en el español de México. Studia Philologica, Homenaje a Dámaso Alonso, II. Madrid: Gredos. 373-385. 
LyONS, J. (1977), Semantics, 1, 2. Cambridge-London-New York-Melbourne: Cambridge University Press.

MARKIČ, J. (1990), Sobre las perifrasis verbales en español, Linguistica XXX. Ljubljana: Filozofska fakulteta. 169-206.

MARKIČ, J. (1991), Hacia un estudio aspectual contrastivo entre el esloveno y el español. Verba Hispanica, I. Ljubljana: Filozofska fakulteta. 105-110.

MATTE Bon, F. (1992), Gramática comunicativa del español. Tomos I, II. Madrid: Difusión S.L.

Miguel APARICIO DE, E. (1992), El aspecto en la sintaxis del español: Perfectividad e impersonalidad. Madrid: UAM.

Miguel Aparicio De, E. (1996), Nominal Infinitives in Spanish: An Aspectual Contraint. The Canadian Journal of Linguistics/La Revue Canadienne de Linguistique. 41(1) March/mars 1996. 29-53.

MIKLIČ, T. (1980), Opozicija perfekt - imperfekt $v$ italijanščini in slovenska dovršnost: nedovršnost za izražanje preteklosti. Disertacija. Ljubljana: Univerza v Ljubljani, Filozofska fakulteta.

MIKLIČ, T. (1981), Kriteriji izbire med perfektom in imperfektom v primerjavi s kriteriji izbire med dovršniki in nedovršniki, italijansko-slovenska kontrastivna analiza. Ljubljana: Univerza v Ljubljani, Filozofska fakulteta.

MiKLIČ, T. (1983), L'opposizione italiana perfetto vs imperfetto e l'opposizione slovena dovršnost vs nedovršnost nella verbalizzazione delle azioni passate. Linguistica XXIII. Ljubljana: Filozofska fakulteta. 53-123.

MIKLIČ, T. (1994/I), Besedilni mehanizmi učasovljanja zunajjezikovnih situacij. Uporabno jezikoslovje 2 (2). Ljubljana. 80-99.

MiKLIČ, T. (1994/II), Segnalazione della temporalità nel testo: che cosa aiuta il ricevente a collocare le azioni sull'asse temporale. Atti del Terzo Convegno S.I.L.F.I. Perugia. (Hrsg. L. Agostiniani).

NeBriJa, E. A. de, (1492/1989), Gramática de la lengua castellana. Ed. de Antonio Quilis. Madrid: Editorial Centro de Estudios Ramón Areces.

OREŠNIK, J. (1994), Slovenski glagolski vid in univerzalna slovnica. Ljubljana: SAZU.

REYES, G. (1983), La realidad de Dicto en Crónica de una muerte anunciada. LEA V/1: 57-69.

REYES, G. (1990/I), La pragmática lingüistica. Barcelona: Montesinos.

REYES, G. (1990/II), Tiempo, modo, aspecto e intertextualidad. RSEL - año 20, fasc.1: 17-53.

REYES, G. (1990/III), Valores estilisticos del imperfecto. RFE, tomo LXX, fasc. 1-2. Madrid: CSIC. 45-70.

RoJo, G. (1988), Temporalidad y aspecto en el verbo español. LEA, vol. X/2. Madrid: ICI. 195-216. 
SKUBIC, M. (1969), Pretérito simple y compuesto en los primeros textos castellanos. Actas del XI Congreso Internacional de Lingüística y Filología Románica. Madrid: CSIC 1891-1901.

SKUBIC, M. (1978), Sur les valeurs du temps du passé dans les langues romanes. Linguistica, XVII. Ljubljana: FF. 143-159.

SмITH, C. (1991), The Parameter of Aspect. Dordrecht: Kluwer.

TACCA, O. (1985), Las voces de la novela. Madrid: Gredos.

VARgas Llosa, M. (1971), García Márquez: Historia de un deicidio. Barcelona-Caracas:

Monte Ávila Editores, C. A.

Corpus:

García MÁrquez, G. (1955/1985), La hojarasca. Bogotá: Editorial La Oveja Negra. (LH) García MÁrQuez, G. (1967/1986), Cien años de soledad, Bogotá: Editorial La Oveja Negra. (CAS)

GARCIA MÁRQUEZ, G. (1970/1986), Relato de un náufrago. Bogotá: Editorial La Oveja Negra. (RN)

GARCíA MÁRQuEZ, G. (1981/1981), Crónica de una muerte anunciada, Bogotá: Editorial La Oveja Negra. (CMA)

García MÁrquez, G. (1985/1985), El amor en los tiempos del cólera. Bogotá: Editorial La Oveja Negra. (ATC)

\section{ASPEKTUALNE VREDNOSTI V SODOBNI AMERIŠKI ŠPANŠČINI V DELIH KOLUMBIJSKEGA PISATELJA GABRIELA GARCÍE MÁRQUEZA}

Pričujoči članek je predstavitev avtoričine doktorske disertacije o vprašanjih aspektualnosti v sodobni ameriški španščini. Avtorica posveča prvi del članka predstavitvi teoretične osnove raziskave, opredelitvi pojma aspektualne vrednosti in predstavitvi tistih glagolskih oblik (nekaterih glagolskih paradigem in glagolskih perifraz), s katerimi se signalizira aspektualnost $\mathrm{v}$ španskem jeziku. Aspektualnost oz. aspektualne vrednosti opredeljuje široko in $\mathrm{s}$ tem terminom zajema tako značilnosti poteka glagolskega dejanja $v$ času (enkratno, ponavljalno, dejanje-navada, rezultativno, itd.), kar se pogosto imenuje vrsta glagolskega dejanja (modo de acción, Aktionsart), kot tudi tip dejanja (stanje, nestanje, telična in netelična dejanja), izbran izsek dejanja (začetni, vmesni - trajajoči, končni), kar je običajno označeno kot faza dejanja, in aspekt $v$ ožjem pomenu besede, kar je najpogosteje opredeljeno kot glagolski vid, aspecto, in izraža, kako govorec gleda na dejanje, s katerega zornega kota ali perspektive opazuje dejanje (dejanje vidi globalno in ga zajema $\mathrm{v}$ celoti ali ga vidi le delno, začetka in konca ne osvetljuje). Širši pristop $k$ proučevanju aspektualnosti $v$ španskem jeziku je potreben zato, ker se aspektualne vrednosti v španščini izražajo drugače kot v slovenščini. 
V tem delu članka so predstavljene tudi nekatere raziskave aspekta španskih in hispanoameriških avtorjev.

Drugi del članka je posvečen analizi aspektualnih vrednosti v pripovednih delih Gabriela Garcíe Márqueza. Korpus raziskave obsega pet del kolumbijskega pisatelja (La hojarasca, Cien años de soledad, Relato de un náufrago, Crónica de una muerte anunciada, El amor en los tiempos del cólera), $\mathrm{v}$ katerih avtorica analizira rabo glagolskih paradigem (enostavni preterit : sestavljeni preterit, enostavni preterit : imperfekt) in glagolskih perifraz za signaliziranje aspektualnosti. Pri tem upošteva besedilno zvrst (roman, kronika), zorni kot pripovedovalca, umestitev drugih diskurzov $\mathrm{v}$ besedilo, pripovedne postopke, reliefiranje dejanja in poskuša ugotoviti, kako pisatelj uporablja omenjena jezikovna sredstva za ustvarjanje lastnega fiktivnega sveta s posebnimi časovnimi in prostorskimi zančilnostmi. Analiza glagolskih paradigem in glagolskih perifraz, ki se uporabljajo za izražanje aspektualnosti, je prispevek $\mathrm{k}$ poznavanju vprašanja aspekta $\mathrm{v}$ španskem jeziku in $\mathrm{k}$ osvetlitvi slogovnih značilnosti pripovednih del Gabriela Garcíe Márqueza. 